\title{
A PROPER LAW OF TORTS IN THE CONFLICT OF LAWS*
}

\author{
PETER J. M. LOWN**
}

\begin{abstract}
The subject examined by this thesis is the conflicts rules which should be applied to determine liability in tort actions, and the question of whether or not a "proper law" approach could be adopted in this particular area. It is submitted, in Section I, that changing circumstances and changing theoretical bases for conflict of laws, are reasons for a fresh look at the area of torts in the conflict of laws. Moreover it is submitted, in Section II, that such a fresh look should be firmly based on fundamental policies of conflict of laws generally, such as the absence of forum-shopping, the convenience of the parties and the achieving of a uniform result whatever the forum of a particular action. The existing rules are examined in the light of their application to the varying circumstances which can arise in tort actions. In addition $a$ critical examination of the existing rules is attempted, in respect of the requirements of identifying the locus delicti, and whether the existing rules relate to choice of law or jurisdictional questions. The "proper law" concept is suggested as a solution to the problems arising from this critical examination, and is buttressed by the operation and use of such a concept in other areas of the law, such as contracts and recognition of foreign divorce decrees. Since the "proper law" approach has been adopted in the United States, it is necessary to examine the experience in those jurisdictions. This examination deals with the "proper law" aspect generally, and more particularly, its application in specific areas such as contributory negligence and vicarious liability. It is suggested that a selective borrowing from the United States experience, excluding the policy gloss which has been placed upon the "proper law" approach in that country, would be profitable in Canada. Finally, it is suggested that a "proper law" approach would be an appropriate solution and is supported by present judicial attitudes.
\end{abstract}

\section{THE CROSSROADS FOR CONFLICTS RULES}

It may safely be said that the doctrine of "stare decisis" is central to the common law legal system and, less safely, that it produces the requisite degree of certainty and predictability, while, at the same time, affording the necessary flexibility to accommodate changing times and conditions, judicial temperaments, and prevailing public policy and morality. It is not at all possible to say that the system is without flaws, and the critical articles and comments which have treated of the subject matter are sufficient evidence of that. The appellate courts, in particular, may cause the legal scholar some analytical searching when he is faced with the prospect of determining the element or elements which form the binding part of any decision. It is in the appellate courts that the possibility of multiple rationes may arise, since each judge may differ in his reasons for reaching a particular conclusion. ${ }^{1}$

In such a situation it is not surprising that some commentators have been moved to say "Quot judices, tot sententiae." Perhaps an illustration can be drawn from the subject of this work, the area of tort liability in the conflict of laws. The case of Boys v. Chaplin ${ }^{2}$ is a unanimous decision of the House of Lords, where five judges agreed that the appeal should be dismissed. In reaching that decision, there were at least three, if not four, separate bases for coming to that conclusion. When the same case was heard by the Court of Appeal, ${ }^{3}$ there

- A Thesis submitted to the Faculty of Graduate Studies in Partial Fulfillment of the Requirements for the Degree of Master of Law in the College of Law, University of Saskatchewan.

- Associate Professor, Faculty of Law, University of Alberta.

1 See Cross, Precedent in English Law 86-90, 96, 97 (2d ed. 1988).

2 [1969] 2 All E.R. 1085.

s [1968] 2 Q.B. 11. 
were also three separate views as to the basis for the decision." The diversity of these opinions is what prompts the question of why the area of tort liability, in its conflicts setting, should be in such a state of flux, and further, in what direction the decisions should be leading.

It may be a truism that the background against which the rules of law operate is constantly changing, but it is this change, and in particular, its rapid rate, which has brought traditional conflicts rules into question. Conflict of laws is municipal law in the sense that it is a body of domestic rules which are brought into play when a transaction, relationship, or event transcends the political boundaries of a political entity and introduces a foreign element into a domestic situation. The greater the incidence of intercourse between the entities, the greater the incidence of "conflicts" situations. To use the words of the American Law Institute, the need for adequate conflicts rules is a pressing one, because: ${ }^{5}$

State and national boundaries are of less significance today by reason of the increased mobility of our population and of the increasing tendency of men to conduct their affairs across boundary lines.

A similar view has been expressed less recently but more forcefully by Goodrich and Scoles. They emphasize that while the economic and social affairs of men have never been limited by political and geographical limits, conflicts rules are directed at making the territorial system of law operate effectively in the trans-territorial affairs of individuals. It is the task of the lawyer, they stress, to make the fact of twentieth century life fit into this political scheme. ${ }^{\circ}$

This pressing need for rules to govern torts in conflicts situations is generated not only by the changes in social conditions, but also by the changes in torts law generally. The movement towards strict liability for manufactured products, liability for negligently caused economic loss, the notion of liability for the creation of risk, as an extension of the concept of breach of duty, ${ }^{7}$ are areas where the law is quite unsettled. Perhaps some of the difficulty of torts in conflicts "stems less from the innate problems of conflicts doctrine than from the turmoil in tort law generated by the sudden emergence of enterprise liability"."

The influence of these two factors, of changing conditions and unsettled torts law, on the conflicts rules in a Confederation, cannot be over-emphasized. In a country where each province must regard the law of its sister province as foreign law, the incidence of conflicts situations is necessarily high. Even if the common law of England is accepted as of a given date, there is no guarantee that this "accepted" law has developed along similar lines in each province." More-

- The three views were: (i) the right to recover damages for pain and suffering is a procedural issue and is governed by the lex fori; (ii) the above-mentioned right is a substantive issue, but on a flexible interpretation of Phillips v. Eyre (1870) L.R. 6 Q.B. 1, the applicable law was English (the forum); (iii) the right to claim damages for pain and suffering should be dealt with by the "proper law" (in this case, English law).

5 Proposed Official Draft, Part II 2 (1968).

- Goodrich and Scoles, Conflict of Laws 5 (4th ed. 1964).

7 See Walker, Delict 49-50 (1966).

8 Ehrenzweig, "False Conflicts" Better Rule: Threat and Promise in Multistate Tort Law, (1967) 53 Virginia L. Rev. at 847-848.

- This assumes, of course, that there is no federal legislation dealing with the situation in question.

10 The date of acceptance varies between 1758 (N.B.) and 1870 (Alta. and Sask.). In addition, it is possible that the conditions prevailing in each province might be significantly different so that the common law might be "applicable" in one, but not in another. See Cote, The Introduction of English Law into Alberta, (1864) 3 Alta. L. Rev. 262. 
over, where the date of acceptance differs widely, there is even less opportunity for uniformity. ${ }^{11}$

There is one further factor that must be mentioned, and that is the close relationship which exists in conflict of laws between the development of the rules and the doctrinal theories underlying conflict of laws generally. ${ }^{12}$ Indeed, some of the present problems may be the result of $a$ priori theorizing that has resulted in what may, at one time, have been common sense rules. ${ }^{18}$

From the era of the post-glossators onward, it is apparent that the political milieu of the "Old World" had much to do with the evolution of "private international law."14 The striving for national existence brought with it concomitant problems of multi-state and multi-national litigation arising out of the commercial intercourse between those states and nations. One of the earlier influential theories was that a foreign law could be applied because of "that courteous intercourse which should subsist between civilized countries."15 Such a rationale was developed to mitigate the rigors of the sovereignty theory, as it had been expounded, ${ }^{16}$ which theory suggested that each ruler must be supreme in his own state, and that any application of a foreign law must necessarily mean an encroachment upon the ruler's supremacy. Essentially, the theory permitted a magnanimous judge to apply a foreign law, where, in his opinion, it was appropriate: ${ }^{17}$

There is, then, not only no impropriety in the use of the phrase "comity of nations", but it is the most appropriate phrase to express the true foundations and extent of the obligations of the laws of one nation within the territory of another. It is derived altogether from the voluntary consent of the latter; and is inadmissible, when contrary to its known policy or prejudicial to its interests.

This theory, however, was doomed to failure for lack of certainty. As Schaffner has remarked, "views of policy, which are the most shifting and uncertain things in the world," 18 would not be appropriate subject matter on which to base a reasoned decision. ${ }^{19}$ The appeal to the "voluntary consent" of the state may well cater to the feelings of national sovereignty, but as a rational theory, leading to predictable results, it leaves something to be desired.

In an attempt to introduce some certainty into the system, two concepts were put forward as providing a satisfactory solution. Both concepts looked to the personality of the parties involved in the conflicts question, and regarded the "personal law" as the law which should be applied in most cases. Some

11 Conditions may have changed considerably between 1758 and 1870, making English law, more or less, applicable on each of these dates.

12 The author does not wish to propound a solution borne only on the wings of popular sentiment. Rather, it is submitted, the eventual solution propounded is a realistic and practical answer to the problem which presents itself. It does seem, however, that conflicts rules are the first aspect of the law to feel the effect of changes in legal theory.

13 The decision in Phillips v. Eyre, supra, n. 4, may be explained as a tortuous attempt to reconcile the result with the vested rights theory.

14 This influence was much wider than in conflicts rules alone. The theories advanced by jurisprudence scholars were, in many ways, an attempt to rationalize the existence of law in society. Thus, Austin's theory of sovereignty was attuned to the notion of one ruler in one state - the effect of such a theory on the territoriality of law, and thus the need for conflicts rules, is obvious.

16 Stiven v. Meyer [1868] Sess. Cas. 370 at 374 per Lord Reaves.

10 See e.g., Bodin, Six Livres de la Republique (1576), and Huber, De Conflictu Legum (1689) for such an exposition.

17 Story, The Conflict of Laws 41-42 (8th ed.).

18 Schaffner, Conflict of Laws s. 30 (1st ed. 1834).

19 It could be argued that the wheel has now turned full circle in that the policy evaluation methods expounded by Cavers, Currie and Ehrenzweig, inter alia, purport to use the very subject-matter which Schaffner was criticising. 
divergence occurred, however, in the means of determining what was, in fact, the "personal law" involved.

The first concept is that expounded in the writings of the distinguished German jurist, Friedrich Carl Von Savigny. ${ }^{20}$ That writer saw that a strict application of the territoriality of law would lead to a complete exclusion from legal rights", as regards aliens. ${ }^{21}$ To adhere to a strict territorial approach would, according to Savigny, afford little help in the solution of a conflicts problem. He supports his argument with the fact that nowhere is such a strict approach taken, ${ }^{22}$ the reason being, he asserts, that, as a result of the "multifarious and active intercourse between different nations" it would not be expedient to adopt such a view. On the other hand, he is not impressed by the opposite view, that of a "friendly concession among sovereign states", in essence, the comity theory discussed above. Such a basis, he stated, implied that the "friendly concession" is of an uncertain and temporary nature, whereas Savigny is seeking a basis to provide a "proper and progressive development of law".23 This latter objective, Savigny submits, could be found, not by dismissing the "comity theory" out of hand, but by regarding it as the embryonic development of a theory which, based on the necessary reciprocity between sovereign states, would lead to the "same decision, whether the judgment be pronouncd in this state or in that."24 According to Savigny, "an approximate uniformity in the treatment of conflicts among different positive laws" 25 could be attained if the premise which he held were accepted; namely, that every legal relationship could be connected in a logical and rational manner with a particular legal system. This "legal seat" could be found in the elements of the relationship, chief among which was the domicile of the parties involved. Only after considering the major element of domicile should the court proceed to other elements such as place of performance or the forum of the action. ${ }^{26}$

Savigny's optimistic belief in such a logical consideration of a conflicts question was not shared by his critics. ${ }^{27}$ The most forceful criticism of this theory is that it ignores the possibility of human choice. As Anton states, ${ }^{28}$ "the centre of gravity of a legal relationship is a matter of human choice, not of logic." Why is it logical, for instance, that the centre of gravity of the marriage relationship should be the domicile of the husband? ${ }^{20}$

If the keynote of Savigny's approach was logic, that of Mancini ${ }^{30}$ was nationality. He regarded nationality as the starting point of international private law, since it was by and for its subjects that a state existed, and territorial sovereignty was merely an adjunct of personal sovereignty. With limited exceptions, ${ }^{81}$ Mancini argued that a person should be governed by, and, outside his home territory was entitled to rely on, the law of his nationality. Mancini's

20 Savigny, A Treatise on the Conflict of Laws (Guthrie's translation, $2 \mathrm{~d}$ ed. 1880). The original work was published in 1849 .

21 Id. at 68.

22 Id. at 69.

${ }^{23} \mathrm{Id}$. at 71 .

24 Id. at $69-70$.

25 Id. at 71.

26 Id. at $132-133,140$.

${ }^{27}$ See Gutzwiller, Principles of International Law Up to the Nineteenth Century, The Theories of Savigny and Mancini, (1929) 29 Hague Recueil at 353.

28 Anton, Private International Law 25 (1967).

29 In Savigny's view there is no doubt as to the correctness of this view. See supra, n. 20 at 291 .

so 1817 - 1888. For his writings, see Diritto Internazionale (1793).

31 Namely, party autonomy in contracts, the principle locus regit actum, and public policy. 
justification for such heavy reliance on the principle of nationality was not logic, as Savigny had tried, but an appeal to emotion. ${ }^{32}$ Perhaps the theory might have had some usefulness if its basic principle had been placed on sure footing but, as Anton asserts, "they took as their foundations premises which no longer command respect and, with little but indifference for practice, constructed upon these foundations an edifice of theory which even the chosen foundations hardly bear." 33

The ongoing attempt to reconcile the theory of sovereignty with the recognition of foreign rights has taken its most influential form in the name of the "theory of vested rights", the rationale of which is that "judges never in strictness enforce the law of any country but their own, and when they are popularly said to enforce a foreign law, what they enforce is, not a foreign law, but a right acquired under the law of the foreign country." ${ }^{34}$ Thus the essence of the theory was that a court enforced only a right which was validly acquired in a foreign country. Much of the body of modern conflicts rules for "classification" is built upon this premise: that the court is trying to ascertain the place of origin of the right and whether or not the right was validly acquired in that place.

In fact the theory invokes completely circuitous argument. If the validity of a right is to be tested by the law of the place of origin, then the means of determining the place of origin are an important and central part of any theory suggesting that solution. The "vested rights theory", however, stops short of that logical corrollary, and does not contain any rules which may be invoked to determine the "place of origin" - as Cheshire expresses it, "the theory begs the question."35

In addition, it is questionable whether the theory is in complete accord with the "command" theory of law expounded by Austin and Kelsen, a claim which is supposedly a large factor in favour of the "vested rights theory". ${ }^{36}$ The view of Beale ${ }^{37}$ is taken as an example: he argues that law is the command of the sovereign and that to give credence to the command of a foreign sovereign would be a breach of sovereignty. However, such a breach can be avoided, he argues, by allowing "the question of validity according to the place of origin, to be proved as a matter of fact." Thus, the court, having determined what the material facts are, applies the command of its sovereign to those facts. It is questionable, however, whether this process is necessary since Beale assumes that the application of a foreign law necessarily involves a breach of sovereignty. This conclusion would not follow if Kelsen's argument were accepted that a state may direct its organs to attach sanctions to a norm which is embodied in the law of another state. ${ }^{38}$ In other words, according to Kelsen, it is possible to distinguish between the content of the law and the sanction attached thereto,

32 For Mancini, the denial of the rights of a private citizen by one state was tantamount to a complete withdrawal of recognition of the state of which that person was a citizen.

33 Supra, n. 28 at 27.

34 Dicey, Conflict of Laws 18 (5th ed. 1932).

35 Cheshire, Private International Law 28 (7th ed. 1965). See also Savigny, supra, $\mathrm{n}$. 20 at 147.

${ }^{36}$ The nub of the theory is that a right must be validly acquired in the place of its origin, and if that is the case, should be endorsed. If this proof is fact or law, some credence is being given to foreign rules of law.

873 Beale, Treatise on the Conflict of Laws 1969 (1935).

${ }^{88}$ See Anton, supra, n. 28 at 33, where he quotes Kelsen, and questions whether the elements of a law, as Austin sets them down, are necessarily inseparable. The same criticism can be directed at the "Local Law" theory, since it may not be necessary to formulate a law in the forum, based on and similar to the foreign laws, provided that the imperative element comes from the former. 
and so long as the enforcing state attaches the sanction, there is no breach of sovereignty. ${ }^{39}$ If it is possible to make a distinction between content and sanction, then the need to prove a valid acquisition of a right in its place of origin becomes redundant. No breach of sovereignty is involved provided that the imperative element of the command emanates from the legal system of the forum. ${ }^{40}$

Professor Cook's disillusionment with the "vested rights theory" led him to proclaim an even stricter version of the territoriality of law."1 His "Local Law" theory states that a judge is to apply only the law of the forum. Where a foreign element is involved, he must formulate a rule of the forum as nearly similar as is possible to the foreign law, and apply the rule so formulated. Here, too, Kelsen's distinction between content and sanction is ignored. There is no need to formulate a law of the forum if there is no breach of sovereignty. Moreover, such an ad hoc approach would give little help to the judge facing a conflicts problem, or the adviser attempting to give counsel, as to what foreign law he is to use as a model. To tell the judge that he may apply the lex fori only, gives him no assistance in the important task of choosing between political units which are competing systems in the case under consideration.

Following the Realist School of jurisprudential thought, there arose a body of opinion to the effect that, in conflicts law, considerably more attention should be paid to the underlying policy of the foreign rule than had previously been the case. ${ }^{12}$ The argument of this school was that a decision based on a dislike for the policy of the foreign rule in alleged clash with the policy of the forum, should be disclosed, rather than hidden behind concepts such as the lex loci delicti. Some of the difficulties this school found hard to bear are summarized by Von Mehren and Trautman: ${ }^{48}$

If courts actually followed a Bealean-Restatement approach, a kind of simplicity, predictability and uniformity would be achieved. However, there is considerable evidence that the courts, though they usually speak the language of the Restatement, are frequently moved by considerations not appropriate in a strict territorial approach.

Now there is nothing entirely novel in this approach, the essence of which is that there may be interests, in a particular case, which demand consideration and which override the application of the normal rules. ${ }^{14}$ The court must not only determine the points of contact made by the conflicts situation, but go one step further to examine the policy of each of the rules of these points of contact. For example, if the forum has a guest-host statute, and the lex loci delicti does not, the courts must consider whether or not the guest statute is designed purely to prevent the perpetration of a fraud on an insurance company, or whether it is primarily designed to relieve the driver from some of his liability. The novelty lies, then, in the particular interests which have been given prominence. In effect, a court confronted by a conflicts problem, must consider the underlying

39 Kelsen, General Theory of Law and the State 244-245 (1961).

10 There may be cases, however, where the forum regards itself as bound to apply a foreign sanction, but only on the basis that the parties have so regulated their affairs that the court decides that the foreign law would be most appropriate.

11 Cook, Logical and Legal Bases of Conflict of Laws (2d ed. 1949).

12 See e.g., Cavers, The Choice of Law Process (1985); Currie, Selected Essays on the Conflict of Laws (1963); Ehrenzweig, Treatise on the Conflict of Laws (1962).

13 Von Mehren \& Trautman, The Law of Multistate Problems 63 (1965). They go on to say that the result was, in fact, a lack of the objectives which the Restatement was alleged to accomplish, namely, predictability and uniformity. This result they attribute to the attempt to formulate a small number of rules to fit a wide and complex subject.

14 The court, for instance, might consider the motive for the choice of forum by the plaintiff. See the comment of Foster J. in John Walker and Sons v. Henry Ost and Company [1970] 1 W.L.R. 917 at 937 (Chancery Division). 
policies behind each possibly applicable rule in order to determine whether there is some interest at stake to protect which, the rule was made law.

It cannot be denied that in conflicts, in particular, it is imperative that a foreign law be taken in its context and that, therefore, the ambit of the application, including the reasons for which the rule was established, be considered most carefully. Before that consideration can be made it is necessary to identify those rules which must be considered, and it is in this respect that the advocates of a "policy-evaluation" theory seem to gloss over an important stage in the reasoning. The approach to a contracts case would be this: given the fact of a contract, which state has a significant connection with the case under consideration? To put the question in that form, it is submitted, leaves out the identification of the primarily interested legal systems: ${ }^{45}$

If we were merely selecting a rule it would be whimsical and random to limit the enquiry to the rules of $X, Y$, and $Z$. We would browse through the rules $A, B, C$, and $D$, and all other legal sources.

It must be that the elements of the transaction related to the states limit our enquiry: the contract was made in $\mathrm{Y}$, performed in $\mathrm{Z}$, and litigated in $\mathrm{X}$. No other basis can be found for isolating these factors from the many.

While purporting to abandon the traditional choice of law rules for determining the applicability of a foreign law (locus delicti, etc.), ${ }^{40}$ these writers are in fact incorporating into the so-called new theory an integral part of the traditional rules. It is in determining the points of contact, or, in other words, those legal systems which might feasibly govern the case, that the traditional rules, such as the place of performance of a contract, or the place where a wrong is committed, are used to bring the court to the stage where a choice of law exists.

Two basic objections can be directed at the policy evaluation theory as it appears in its more recent form. In the first place, it is arguable that a judge, when asked to decide what are the underlying purposes behind a particular rule, is facing an impossible task: ${ }^{47}$

But interest analysis commits us to the analysis of the reality underlying legal rules, including the purposes underlying the application of the rule to the very case at bar -

States do not make legal rules; neither do they love, hate, feel or have concerns and

interests. You cannot search New York's craggy old face and find the meaning of concern.

Is it possible to determine the underlying policy of each rule in the legal system? Even if that was the case, it does not mean that the rule was established with the fact being recognised that this policy might be considered in a conflicts problem.48 "Underlying policy" and "substantial connection" are two quite different species, and the present writer is not at all convinced that an "underlying policy" can be satisfactorily adduced in every case.

The second and perhaps more cogent criticism is the tendency of those following this theory to be markedly biased in favour of the forum. Two reasons may be put forward in an effort to explain this illiberality towards foreign law. The theory seems to have undergone a fundamental change, during its formative years, from a close consideration at the stage where a choice of law exists, to a fully fledged theory for determining whether or not a choice of law exists at all.

45 Ewing, Choice of Law and the Borrowed Fictions of "Interest Theory", (1968) Houston L. Rev. 28 at 34.

46 The earlier members of this school did not purport to abandon the traditional rules, but later members desired to do this in whole or in part. $C f$. Cheatham and Reese, Choice of the Applicable Law, (1952) 2 Colum. L. Rev. 957, with Currie, supra, n. 42.

47 Supra, n. 45 at $44-45$.

48 The dissenting judgment of Roberts J. in Cipolla v. Shaposka (1970) 267 A. (2d) 854 (Supreme Court of Pennsylvania), points out the inherent difficulties of such an enquiry. 
The question no longer is: Which legal system has the most substantial connection with the case?; but rather it is: Does the forum have an interest in the case which is worth protecting? An affirmative answer to the latter question will almost certainly lead to the application of the lex fori. It is apparent that the theory has wavered some way from its original starting point. For example, the question in Babcock v. Jackson ${ }^{4 \theta}$ would under this theory be: Does New York have an interest in guest cases involving New Yorkers? On the facts of the case, however, the question is surely not the most appropriate. The locus delicti being purely fortuitous, was there another legal system which had a more substantial connection with the tort? ${ }^{30}$

Some of this difficulty can be traced, as Professor Anton asserts, ${ }^{51}$ to the tendency to view all conflicts cases as conflicts of state interests. When viewed in this light, a judge will be loathe to do other than protect the interests of his own state. The duty of the court is not to determine "the appropriate rule of decision when the interest of two or more states are in conflict - in other words, of determining which interest shall yield," state may have in giving effect to its legislative policies must be weighed against the need to give effect to the reasonable expectations of the parties." ment serves well to emphasize that the cases must look to the justice of the decision as between the parties with the proviso, however, that a court should not entertain a rule which is contrary to the public policy ${ }^{54}$ of the forum.

\section{CHOICE OF LAW POLICY}

Before any valid criticism can be levelled at the traditional rules regulating torts in the conflict of laws, it is imperative that the criteria upon which these rules are based and the objectives which these rules seek to achieve, be set forth for examination. ${ }^{\text {ss }}$

The raison detre of conflicts rules is a desire to obviate some of the bizarre results that would occur if each jurisdictional unit applied only its own internal law in every case. Goodrich expresses it thus: ${ }^{56}$

Fairness to the parties demands that the obligations created between them remain unchanged by fortuitous changes in the geographical locations of either until such obligations are settled or otherwise discharged.

This is but another means of expressing the notion that, as far as possible, a uniform result should be achieved in a given conflicts case, regardless of the place where the case is heard. It is precisely this desire that prompted Hancock to state: ${ }^{57}$

The principle that tort claims are regulated by the law of the place of the wrong would obviously be appropriate.

It would seem only fair and just that courts should attempt to reach a uniform result in similar conflicts cases. If this were not the case, then the plaintiffs

19 (1963) 191 N.E. (2d) 279 (New York Court of Appeals).

so Babcock v. Jackson was a comparatively simple case in that the points of contact were quite clear. However, it is submitted that the second question is more appropriate even where the points of contact are not so clear.

51 Anton, supra, n. 28 at 41.

52 Currie, supra, n. 42 at 178.

ss Anton, supra, n. 28 at 41.

64 It is another question entirely how one determines the "morality" of the forum.

55 Throughout this section these criteria and objectives will be referred to as "choice of law policy", that is to say, some of the basic aims of conflicts rules in general.

${ }^{58}$ Goodrich, Public Policy in the Conflict of Laws, (1930) 36 West Virginia L.Q. 156 at 164 .

${ }^{57}$ Hancock, Torts in the Conflict of Laws 55 (1942). 
remedy would vary with the choice of the forum and "forum-shopping" would become a real possibility. ${ }^{\mathrm{s}}$

There are, however, two important caveats to this desire for uniformity. In the first place, uniformity is not a practical indicator as to which law should be applied. Uniformity could be achieved by applying the law of Utopia to all contract cases, and the law of Timbuktu to all tort cases, but this would hardly be a fair result in an action between two Canadians from Ontario who were involved in a traffic accident in Quebec. ${ }^{.9}$ In the second place, this notion must encounter great difficulty in that the rules of each jurisdiction differ quite considerably, and in some cases, it may be necessary to surrender the desire for uniformity of result in favor of a just decision in the particular case. ${ }^{60}$ Even in those cases, however, there is a saving clause which will operate if the divergence is so great that the forum has no appropriate enforcing machinery or the concept in the foreign law is repugnant to the public policy of the forum.

This leads naturally to the second "policy" which, for want of a better term, has been called the "convenience of the parties". The lack of uniformity of result as between different jurisdictions leads to rather more disastrous results for the defendant than the plaintiff. The plaintiff is at liberty to choose, from among those appropriate jurisdictions, the forum which is most favorable to his cause. Moreover, since there is no doctrine of merger in conflicts law, ${ }^{01}$ he is quite at liberty to sue afresh on the original cause of action in another appropriate jurisdiction.

There are, however, some small crumbs of comfort to console the beleaguered defendant. Even if it is conceded that the forum chosen by the plaintiff does have jurisdiction, it may be possible to raise the plea of "forum non conveniens", in an attempt to counteract the plaintiff's choice of forum. The remarks of Foster, J. in John Walker and Sons v. Henry Ost and Company Limited ${ }^{62}$ show, in a negative fashion, that he might have been prepared to entertain such a plea in response to an allegation that the plaintiff was forum-shopping. On the other hand, this is not the easiest of pleas to substantiate, ${ }^{63}$ and the defendant must show considerable hardship before the plea will be sustained. ${ }^{64}$

58 The possibility of "forum-shopping" is probably the practice which should be most avoided in conflicts cases. See Clark v. Clark (1966) 222 A. (3d) 205 at 208 (New Hampshire Supreme Court).

50 Unless, of course, the law of Utopia or Timbuctu, as the case may be, was similar in content to that of Ontario or Quebec.

${ }^{60}$ Perhaps the best example of such a case is the difficulties that have been experienced over the "domicile" and "nationality" criteria which are applied in Family Law, and to questions of status.

61 This is supported in Monast v. Provincial Insurance Company of England [1939] 4 D.L.R. 814 (Ont. S.C.), where an award of damages arising out of a traffic accident did not merge the original cause of action. There is some criticism of this statement on the basis that the doctrine of non-merger was required only where a judgment could be impeached on its merits. Since that is no longer the case, and a judgment can no longer be impeached on the merits, it is argued that the doctrine of non-merger is not appropriate. See Read, Recognition and Enforcement of Foreign Judgments 111 (1938).

62 Supra, n. 44 at 937.

68 See Re Norton's Settlement [1908] $1 \mathrm{Ch} .471$, where the court sustained such a plea but the evidence pointed overwhelmingly to that conclusion. (Marriage settlement made in India, husband and trustees resident there, settled property situated there, and defendants on purely temporary visit to England).

64 In addition, it would seem that the latitude of the rules providing for service out of the jurisdiction would reduce the benefit of the plea of forum non conveniens. If a court has permitted service ex juris then it would seem inconsistent to say, at a later date, that the chosen forum is not convenient. Even though the questions of service ex juris and forum non conveniens arise at different stages, it is submitted that the practical combination of the two affords little benefit to the defendent. See e.g., Alta. Rules of Court 30, 31. 
Moreover, in any action where a limitation period is in question, the limitation is regarded as being a matter of procedure, and subject, therefore, to the lex fori. ${ }^{65}$ This classification of prescription, as a matter of procedure generally, could work considerable injustice to the defendant since the plaintiff may choose a forum with the longest limitation period. ${ }^{66}$ Similar considerations apply not only to a period in which an action for damages must be brought, but also to the limitation on the amount of damages which may be recovered. Only if the prescription in question can be regarded as going to the heart of the right in issue, will the matter be regarded as one of substance, ${ }^{67}$ but this will be a matter of classification, the cardinal rule of which is that classification is made according to the lex fori. ${ }^{68}$ Thus, for the purpose of limitation of actions, the choice of forum by the plaintiff could be crucial. ${ }^{69}$ It is submitted that there is a balance of interests between the parties in any case, and that this balance could conceivably be upset by the choice of forum in that case. The court should be aware of this possibility, and should be careful to ensure that one or other of the parties is not deprived of the possibility of presenting or preparing his case properly by reason of the choice of forum.

Three further aims merit consideration under the heading "choice of law policy". Somewhat similar to the idea of the "convenience of the parties" is the suggestion that some account be taken of the "reasonable expectations" of the parties. This concept takes on different forms in contract and tort in that it is probably easier in the former to determine what were the intentions or expectations of the parties. In the latter, the intentions or expectations must be determined objectively and ex post facto. This does not mean that the reasonable expectations of the parties who eventually become embroiled in a torts situation, should be disregarded. Indeed, there can be situations where this factor is of the utmost importance. In the case of Clark v. Clark, ${ }^{70}$ it is apparent that the parties would not have contemplated the application of the law of Vermont, which was in fact the lex loci delicti. Examples of this, where people work and live close to the border of another jurisdiction unit, could be multiplied. ${ }^{71}$ Moreover, there

65 Compania Columbiana de Seguros v. Pacific Steam Navigation Co. [1964] 1 All E.R. 216 at 233 (Queen's Bench).

66 Morris argues that the unfortunate result which came about in McElroy v. McAllister [1949] Sess. Cas. 110 could have been avoided by a more prudent choice of forum and the use of service ex juris. See (1949) 12 Mod. L. Rev. 248.

${ }^{67}$ Leroux v. Brown (1852) 12 C.B. 801 (Court of Common Pleas).

68 Except in respect of immovables. For the rule see Huntington v. Atrill [1893] A.C. 150.

69 See the cases of Harris v. Quine (1869) L.R. 4 Q.B. 653, where the English court allowed an action on a debt incurred in the Isle of Man, notwithstanding that the Manx Courts had held the debt to be irrecoverable due to a local prescription law; and British Linen Co. v. Drummond (1830) 10 B. \& C. 903 (King's Bench), where an action was brought in England in respect of a contract made in Scotland, and the shorter limitation period of six years under English law (the lex fori) was preferred to the forty year period under Scots law. This problem is exacerbated by the tendency to attempt to fit the foreign rule into the existing categories of the lex fori, rather than a genuine attempt to determine the nature of the foreign rule in the context of the foreign law. See Simonin v. Mallac (1860) 2 SW. \& TR. 67 (Court for Divorce and Matrimonial Causes).

70 Supra, n. 58. In this case the parties, husband and wife, were domiciled and resident in New Hampshire. Presumably, the automobile was garaged and insured there. One evening, the parties set out on a trip to Littleton, also in New Hampshire. In the course of the journey the parties motored into Luneburg, Vermont, where they were involved in a motor vehicle accident. The law of Vermont, the locus delicti, had a guest statute, whereas New Hampshire, the lex fori, had no such limitation. In giving judgment, and applying the law of New Hampshire as the "proper law", the court, at 209 , pointed out that this choice of law would accord with whatever advance expectations the parties might have had.

71 The town of Lloydminster, which straddles the boundary between Alberta and Saskatchewan, is an example close to home. 
are many areas where the possibility of travel between units is extremely likely, even though the situation may not be so obvious as a border town. Thus, in Babcock v. Jackson ${ }^{72}$ it was recognised that the reasonable expectation of the parties was that the law of the place where they lived and worked, and where their excursion was to begin and end should govern their conduct inter se.

A second factor which must be considered is the position of the locus delicti. It is arguable, even in cases involving entirely foreign elements, that the locus delicti has a substantial interest in controlling and regulating the events which take place within that locus. The mere fact of being a foreigner should not provide a licence to contravene the rules of the locus delicti. This argument is upheld in criminal respects, in that criminal law is regarded as purely local character and criminal conduct within a particular area is regulated by the laws of that area alone. ${ }^{73}$

Finally, some protection must be afforded to the lex fori. It would be a travesty to insist that the forum should apply a foreign law wholesale, without any regard to the public policy and morality of the forum. Thus a court may decline to assist persons in circumventing the laws of another country. ${ }^{74}$ There is a danger, however, that this discretion could be carried to an extreme by a judge who is prone to expressing subjective opinions, but, it is submitted, an adroit use of the concept of "public policy", can provide the necessary degree of protection to the law of the forum. Mere differences in legal responses should not invoke the concept, but rather a head-on collision of policies and underlying motives. $^{.5}$

\section{THE SCOPE OF THE PROBLEM STATED}

Much of the discussion over the unsatisfactory state of torts rules in the conflict of laws was stirred by the article written by Dr. J. H. C. Morris, and published in 1951..76 The gist of his argument was that, though the locus delicti was usually closely connected with a tort, there could and would be cases where this connection was rather tenuous. To illustrate his point he cites the example of an American co-educational school which establishes a summer vacation camp in a fairly isolated part of northern Quebec. All the personnel involved are American and are instructors or students in the school. During the course of the camp, one of the girls is seduced by one of the boys so that she becomes pregnant, and another girl is bitten by a dog which is being kept in the camp by one of the boys. Neither event would have taken place but for the negligence of the camp organizers. Morris argues that it makes no sense to hinge the question of recovery by the girls or their parents on the Law of Quebec.77

The argument which Morris advanced is a strong one, and the more so because the example chosen by him is by no means unreal or unlikely. Similar situations will often arise wherever travel between, across and over separate legal units is comparatively easy - the provinces of Canada, the states of the United States of America and the countries of Europe are areas where such intercourse is commonplace. It is not unreasonable to foresee that two New York

72 Supra, n. 49.

${ }_{73}$ "The common law considers crimes as altogether local, and cognisable and punishable exclusively in the country where they are committed . . " Story, Conflict of Laws, supra, n. 17 at s. 620-621 (8th ed. 1883). See also Addams v. Worden (1855) 6 L.C.R. 237 especially at 240-241 (Queen's Bench, Appeal side).

74 See Foster v. Driscoll [1929] 1 K.B. 470, and Regazzoni v. Sethia [1956] 2 All E.R. 487, aff'd. on appeal [1958] A.C. 301.

75 This will be considered further (infra) when the first part of the rule in Phillips v. Eyre is discussed.

${ }^{76}$ Morris, The Proper Law of a Tort, (1951) 64 Harv. L. Rev. 881.

IT Id. at 885 . 
residents might plan and carry out a week-end fishing trip in Ontario; ${ }^{78}$ or that the occupants of a place might overfly a number of states while travelling between two points in the United States; ${ }^{70}$ or that a trawler operating out of British Columbia might meet a Russian fishing boat only a short distance from the Canadian coast; ${ }^{80}$ or that a company in England might manufacture drugs which are eventually sold in Australia; ${ }^{81}$ or that two British servicemen might be involved in an automobile accident while on service in Malta. ${ }^{82}$ Such examples could, of course, be multiplied ad infinitum. . $^{\mathrm{s3}}$

Various types of conflicts cases can be described and distinguished. Consider the following three examples:

A. Two Scottish businessmen, A and B, embarked upon a business trip to Sweden, and part of the trip involves attendance at a Board of Trade dinner. After cocktails, A hears that B has clinched a deal, in secret, which he himself expected to obtain. Believing this to have been done by underhand methods, $A$ makes a statement to $B$, audible by all the other international businessmen standing by, to the effect that $B$ is a thief and $a$ liar, and that he, $A$, intends to have $B$ run out of business on account of his underhanded dealings. This accusation is in fact quite unfounded.

B. John Doe, domiciled and resident in British Columbia, is in the course of a return airtrip from his home to Newfoundland. The airline company is a Dominion company with its head office in Ontario. While changing flights in Quebec, Mr. Doe disembarks from the plane onto a flight of steps, which looks perfectly safe. In fact the steps give way when Mr. Doe stands on them and he sustains serious injury.

C. Mr. and Mrs. Bright, resident and domiciled in North Dakota are on a camping holiday in northern Saskatchewan. Despite warning notices about the danger of forest fires, Bright is negligent in leaving his campfire unattended, as a result of which a fire starts and is not extinguished until it has burned down the cabin of a local resident.

If these examples are analysed they can be seen to represent three general classes of torts cases which will arise in the conflict of laws:

A. The first is a tort committed solely as between the parties, since it matters little where the statement was made. The reasonable expectation of the parties would be to assess the statement and the consequences thereof by their own law', namely, Scots law. In particular, the locus delicti is not only fortuitous, but also another law presents itself logically and rationally as that to be applied. ${ }^{84}$

B. The second case shares some of the elements of the first, especially those which lead to the conclusion that the locus delicti bears little relation to the

${ }^{78}$ Babcock v. Jackson, supra, n. 49.

${ }^{79}$ Kilberg v. North East Airlines (1961) 172 N.E. (2d) 526 (New York Court of Appeals).

80 Gronlund v. Hansen (1968) 69 D.L.R. (2d) 598 (County Court), aff'd. on appeal (1969) 4 D.L.R. (3d) 435 (B.C.S.C.).

81 Thompson v. Distillers Co. (Bio-Chemicals) Ltd. (1968) 88 W.N. (Pt. 2) (N.S.W.) 219 (Court of Appeal).

82 Boys v. Chaplin, supra, n. 2.

83 Perhaps one of the leading examples where only a small distance was involved, but where the results differed considerably, is the case of McElroy v. McAllister, supra, n. 66, where a Scots widow was unable to recover damages for the death of her husband on the basis that the accident, in which he was killed, occurred in England.

84 This is the type of case with which the courts were confronted in Babcock v. Jackson, supra, n. 49, and Szalatnay - Stacho v. Fink [1947] I K.B. 1. 
'center of gravity' of the tort. However, it differs from the first, since at first blush, no law clearly presents itself as the law to be applied.8s

C. The third case contains facts that suggest that the locus delicti is not merely a matter of casualness, but rather has a great deal of relevance to the case at bar. ${ }^{86}$ Here it would be a weak argument to say that it was a reasonable expectation of the alleged tortfeasor that his conduct should be governed by a law other than the lex loci delicti.

\section{Application of the Traditional Rules}

That the traditional rules are rigid and inflexible, and in some cases unjust, may be seen by applying them to the three examples given above. The traditional common law rules state that two tests must be satisfied. ${ }^{\mathrm{st}}$

(a) The act must be actionable as a tort by the lex fori.

(b) The act must be 'not justifiable' by the lex loci delicti.

It is clear that the emphasis is placed on the lex foris and it is this law which represents the guiding force. ${ }^{80}$ What is the result if these rules are used to solve the three examples?

A. Assume the action were brought in England. It would be necessary to show that the act was not justifiable by the law of Sweden (locus delicti) and that it was actionable as a tort by the law of England (forum).

The discussion would be largely upon the actionability as a tort, of the acts complained of in England, provided there was some kind of sanction, either civil or criminal, in Sweden. Under the traditional rules, the law of Scotland would have no relevance whatsoever. It would appear that the order of priorities for the choice of law here, ought to be Scotland, Sweden, and England, whereas the double rule reverses this order and ignores the third (Scotland) altogether.

B. Once again, the test would be 'actionability' by the lex fori and 'nonjustifiability' by the lex loci delicti. First, it would be necessary to show that the act was not justified by any provision of the law of Quebec, that is, that some sanction would attach to the use of unsafe equipment. In other words, for the action to be successsful, the act in question must have been not justifiable by the law of Quebec, being the locus delicti. Secondly, it would

85 Here the facts disclose similar issues to those raised in Kilberg v. North East Airlines, supra, n. 79. One argument employed by the courts has been to classify the question as a "contracts" problem, thereby opening the way for an application of a "proper law" approach; making use of points of contact such as the place of contracting, the domicile of the parties. See Levy v. Daniels U-Drive (1928) 143 A. 163 (Supreme Court of Errors of Connecticut).

86 This is the type of rule which, considered in isolation, would most definitely be considered a rule of "substance" rather than "procedure".

87 This emphasis may be contrasted with a similar double rule in Scots law, where, however, the emphasis is more on the locus delicti. In that jurisdiction three tests must be satisfied:

(i) actionability by the lex loci delicti as a delict,

(ii) actionability by the lex fori at the date of action,

(iii) the act must confer a right of action on the same person in the same capacity. This double test may give more flexibility since the determination of the locus delicti is not as mechanical or simple as the determination of the lex fori. Despite this shift in emphasis the rules may still work injustice, as Lord Keith hastened to point out in McElroy v. McAllister, supra, n. 66 at 132.

${ }^{88}$ As enunciated in Phillips v. Eyre, supra, n. 4 and Machado v. Fontes [1897] 2 Q.B. 231.

${ }^{89}$ There is some argument to the effect that the lex fori does not have such control, because the rule is one of choice of jurisdiction and not choice of law. (This argument will be taken up later). 
be necessary to show that the act was tortious by the lex fori. This second factor raises a two-fold question as to the place where the action is brought and the grounds upon which the action is based. It is conceivable that the action could be based upon occupier's liability, breach of contract, or vicarious liability for the acts of servants. Assume, for the purposes of the example, that the action is brought against the defendant airline company, alleging negligence on the part of the company's servants. The grounds for the action are now settled, but the action may be brought in British Columbia, Quebec, Ontario or Newfoundland. Each of these jurisdictions may vary in its requirements for the proof of negligence, the basis of the liability of a master for the acts of his servants, and the proof of consequential damage. In this situation, the choice of the forum may, in fact, be the deciding factor in whether the litigation succeeds or fails.90

C. In this example, the locus delicti is not hard to identify and since there are warning notices concerning the dangers of unattended camp fires, it was probably reasonably foreseeable that damage would result from failure to keep a careful watch on Bright's camp fire. The choosing of the forum may be of extreme importance here. If Mr. Bright is resident in North Dakota and has assets there which might satisfy a judgment it might be advisable to sue him there, especially since his stay in Satskatchewan is unlikely to constitute more than "fleeting presence". On the other hand, if it were fairly clear that the law of North Dakota would regard the loss as too remote to be recovered, it might be necessary to sue in Saskatchewan. This could be done by service ex juris $s^{91}$ on the basis that the tort was committed within the jurisdiction. The next stage would involve the enforcement of the judgment in North Dakota, but that would be less difficult than being put to the proof, in North Dakota, of a claim in tort. Here again, the choice of forum is crucial, leaving the locus delicti a rather insignificant role.

It is in this kind of example that the traditional rule in Phillips v. Eyre seems to have a rather misplaced emphasis. The actings out of which the action arises are apparently much more closely connected with the place where they were carried on than the particular place where the plaintiff chooses to bring his action. The rule in Phillips v. Eyre emphasizes the actionability of the acts complained of, in the lex fori rather than the lex loci delicti.

It is suggested that these three examples epitomize, but not necessarily exhaust, the classes of cases which may arise in torts in the conflict of laws. They serve well, it is submitted, to illustrate the inflexibility of the double test. Each case discloses a different issue - the first is an interpersonal tort affecting only the parties involved, while the third revolves around a rule of conduct in a given place. The double test treats all three cases alike. What flexibility it does allow depends on the choice of forum, a factor which goes against the grain of two of the basic aims of conflicts rules - the discouraging of "forum shopping" and the achievement of a uniform result wherever a given set of facts is considered.93

\section{THE TRADITIONAL RULES STATED}

The conditions of actionability at common law demand further consideration. As stated in Phillips v. Eyre ${ }^{04}$ they are as follows:

(i) The wrong must have been of such a character that it would have been

${ }^{80}$ Provided the double test is regarded as pertaining to choice of law and not jurisdiction.

91 E.g., Sask. Revised Rules of Court 27(e) Order IV.

92 Supra, n. 4.

03 See II. Choice of Law Policy.

94 (1869) L.R. 4 Q.B. 225. 
actionable if committed in [England]. ${ }^{95}$

The effect of this rule is to impose an English classification (or that of the forum) on all conflicts cases involving torts. Thus, in The Halley, ${ }^{90}$ it was a good defence that English law imposed no liability on shipowners whose ships had done damage while compulsorily under the control of a pilot. A further example would revolve around a breach of promise of marriage committed in France. Despite being tortious in France, this would not be actionable as a tort if committed in England". ${ }^{97}$ For the same reasons, an English court would be required to treat all foreign defamatory broadcasts according to the peculiarly English definition contained in the Defamation Act 1952.8 This effect, of imposing the classification of the forum even on foreign actings, is the more strange since it has not occurred in other areas of the law. ${ }^{99}$

(ii) The act must have been "not justifiable" by the lex loci delicti.

This statement is explained by Rigby, L. J. in the case of Machado v. Fontes, ${ }^{100}$ where he stated: ${ }^{101}$

The innocency of the act in the foreign country is an answer to the action. That is what is meant when it is said that that act must be "justifiable" by the law of the place where it was done.

The platform upon which this statement rests is that the decision in Phillips v. Eyre ${ }^{102}$ had made a deliberate change in the rule by substituting "not justifiable" for "actionable". However, as Cheshire ${ }^{203}$ cogently argues, a perusal of the remarks of Willes J. reveals no such intention, the remarks being limited to "the civil liability arising out of the wrong" ${ }^{104}$ Further support for this view can be found in the Court of Appeal judgment of Lord Denning in Boys v. Chaplin, ${ }^{105}$ where he combines the dicta of Willes J. and of Wightman J. in Lord Seymour v. Scott. ${ }^{106}$ Willes J. stated that he declined to disagree with the opinion of Wightman $\mathrm{J}$. who had expressed sentiments quite contrary to the interpretation later placed on the rule in Machado v. Fontes. ${ }^{107}$

The meaning of the term "not justifiable" is not limited to a lack of that quality in the tortious sense alone, but merely means "not justifiable" as between the plaintiff and the defendant by reason of crime, breach of trust, breach of contract or other wrongful nature. Thus the "fellow servant" rule may lead the court to say that an act was justifiable in the place of commission, and that no

25 The statement of this part of the rule has been altered in the eighth edition of Dicey so as to take account of the views of Falconbridge (1st ed. at 696-697) and Willis, (1936) 14 Can. Bar Rev. 21. The rule states: "an act, . . . if done in England ..." The rule is acknowledged by the editors as referring to choice of law rather than jurisdiction. Yntema argues that the rule requires only that the case be triable in England, thus excluding, for example, trespass to foreign land [(1949) 27 Can. Bar Rev. 116].

96 (1868) L.R. 2 P.C. 193.

97 See Dicey \& Morris 926-927 (8th ed.).

${ }^{98}$ Defamation Act. S. 1, and Wireless Telegraphy Act s. 16(3), 15-16 Geo. 6 and 1 Eliz. 2 c. $66,12,13$ \& 14 Geo. 6 Vol. 1 c. 54.

99 See particularly In re Bonacina [1912] $2 \mathrm{Ch}$. 394, where an Italian transaction, lacking "consideration", according to the English definition, was nevertheless enforced in England.

100 Supra, n. 88.

$101 \mathrm{Id}$. at 235.

102 Supra, n. 94.

103 Cheshire, supra, n. 35 at 247.

104 In Koop v. Bebb (1951) 84 C.L.R. 629, the High Court of Australia has expressed the opinion that Machado v. Fontes has unduly widened the scope of the rule.

105 Supra, n. 3.

108 (1862) 1 H. \& C. 219.

107 Supra, n. 88. 
action was maintainable in the forum. ${ }^{108}$ This condition may work injustice in another direction by creating rights in the locus delicti that do not in fact exist there. There will be situations where an act is unjustifiable in the locus delicti but will not give rise to tortious liability, that is, in the locus delicti there is a valid defence to an action in tort. Under the traditional rules, however, this differentiation by the lex loci delicti will be of no avail. The act being unjustifiable, the precise mode of redress is a procedural matter, to be determined by the procedural laws of the lex fori. One of the most criticized cases ${ }^{10 \theta}$ in conflicts law arose under this very argument: a libellous pamphlet printed in Portuguese was published in Brazil, the law of which country provided that such action gave rise to criminal proceedings but did not afford a civil remedy; in an action for damages in England the court held that such an action was competent since the act was not justifiable in Brazil, it did not matter that no civil remedy was available in Brazil since that was a matter of procedure in the law of Brazil.

An integral part of the traditional rules, and a prior question to the determination of actionability by the lex loci delicti, is the decision as to what is the locus delicti, a process not without its difficulties. Many of the decided cases must be handled with care, since they arise under the rules dealing with service ex juris, ${ }^{110}$ and the element of judicial discretion in those cases must be borne in mind. Further difficulty is encountered in views as to the differing stages at which a tort exists, especially if the view is accepted that the locus delicti is the place where resultant harm is suffered. These difficulties will become more apparent as the divergent views are discussed. Graveson has suggested ${ }^{111}$ that the identification of the locus delicti is free from doubt in most cases, but, it is submitted, it is not a question which can be conveniently brushed under the carpet.

The first of the possible formulae is expounded by Wolff ${ }^{112}$ to the effect that locus delicti is the place where the defendant took the action necessary to commit a tort. Thus, for example, the locus delicti in a case of the negligent manufacture of goods, would be the place where the goods were manufactured. Strong authority for this view is in the judgment of Du Parcq L.J. in George Monro Ltd. v. The American Cyanamid \& Chemical Co., ${ }^{118}$ a case which arose out of the sale, by English distributors, of rat poison manufactured in the United States. Du Parcq L.J. stated: ${ }^{114}$

The principle of the rule is plain. Looking at the substance of the matter, without regard to any technical consideration, the question is: where was the wrongful act, from which the damage flows, in fact done? The question is not where was the damage suffered, even though damage may be the gist of the action.

In that case the court denied leave to serve ex juris on the basis that the action was not founded on a tort committed within England. A similar approach was adopted in Cordova Land Co. Ltd. v. Victor Brothers Inc., ${ }^{115}$ where the court declined to allow service ex juris in respect of an alleged tort of fraudulent misrepresentation, the misrepresentation being made in the United States and acted upon in England with resultant loss. The remarks from the bench disclose the difficulty in relying on cases under service ex juris as authority in the

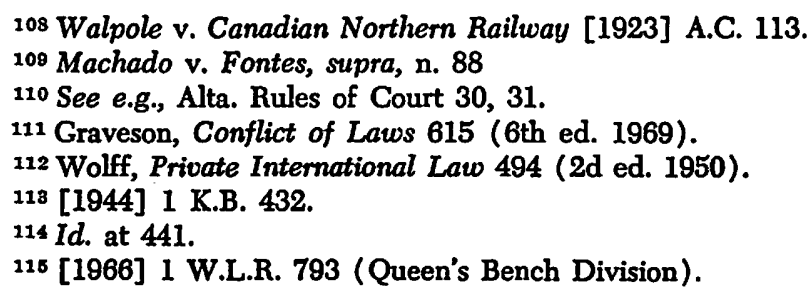


identification of the locus delicti. Winn J., having conceded that the representation was made in Boston with the knowledge that it would be received in England, declines to exercise his discretion in favour of leave to serve ex juris, and concludes by saying: ${ }^{116}$

On balance there is more that has to be investigated and litigated elsewhere than in England.

This first view was taken to its most extreme in the case of Abbot-Smith v. Governors of University of Toronto. ${ }^{117}$ The action in that case was brought against the defendants on the ground of the alleged negligent manufacture, in Ontario, of oral polio vaccine some of which had been administered to the plaintiff in Nova Scotia, and as a result the plaintiff suffered permanent damage. Service ex juris was denied on the grounds that all the elements of a tort, namely, duty, breach and damage, had not occurred within the jurisdiction. ${ }^{118}$

This first view would appear to say that the locus delicti is the place from which the harm ensues. Certainly, the mere fact that harm has been suffered within a jurisdiction will not automatically lead to leave to serve ex juris on the basis that a tort has been committed or a wrong done within that jurisdiction. The cases suggest that the occurrence of harm in a particular place is not sufficient evidence that that is the locus delicti, and the opinions tend to lean towards the place of acting. ${ }^{119}$

The second view attributed much more weight to the place where harm occurs, and the argument is buttressed by the statement, for example, that negligence can not exist in the air, and that a tort is not complete until a duty has been breached, and damage has been suffered. ${ }^{120}$ In the case of Bata v. Bata, ${ }^{121}$ the Court of Appeal granted leave to serve ex juris where defamatory letters had been written and posted in Switzerland, and received in England. Counsel for the plaintiff argued, on the basis of the decision in Monro, ${ }^{122}$ that the tort had been committed in Switzerland, but the view of the court was that no locus delicti could be pin-pointed until there was in fact a tort (i.e. breach of duty and resultant damage) and that the tort, therefore, must have been committed in England. ${ }^{123}$ A similar decision was expressed in Original Blouse Co. v. Bruck Mills, ${ }^{124}$ where representations were made by letter and telephone from Quebec to British Columbia. Aikins J. granted leave to serve ex juris on the ground that a tort had been committed in British Columbia. However, it is clear that there were factors additional to the occurrence of loss which influenced his decision: ${ }^{125}$

... the defendant made a false representation to the plaintiff in British Columbia, the plaintiff was induced in British Columbia to act on that false representation, and having done so suffered loss in British Columbia.

In the case of Jenner v. Sun Oil Co., ${ }^{128} \mathrm{McRuer}$ C.J.H.C. granted leave to

116 Id. at 802.

117 (1964) 45 D.L.R. (2d) 672 (N.S.S.C., on appeal).

118 Coffin J. relied heavily on the case of Beck v. Willard Chocolate Co. [1924] 2 D.L.R.

1140 (N.S.S.C., on appeal) and reluctantly concluded that he was bound by that decision (see at 73).

119 See e.g., Distillers Co. (Bio-Chemicals) Ltd. v. Thompson [1971] 1 All E.R. 694, especially at 698-700.

120 See Jenner v. Sun Oil Co. [1952] 2 D.L.R. 526 (Ont. H.C.), as to the element of publication in a defamation action.

121 [1948] W.N. 366 (Court of Appeal).

122 Supra, n. 113.

123 Publication of the libel being an essential element of the tort, the court was impressed by the fact that publication had in fact taken place in England.

124 (1963) 42 D.L.R. (2d) 174 (B.C.S.C.).

125 Id. at 183. 
serve ex juris where alleged defamatory material had been broadcast in the United States and heard in Ontario where the plaintiff suffered damage to his reputation. Some reliance was placed on the decision in Bata, ${ }^{127}$ and especially the comments that the act of publication was of the essence of the tort. A number of other cases have adopted a similar view: Longworth v. Hope, ${ }^{128}$ where an alleged slander was printed in a journal which was circulated in Scotland; Thomson v. Kindell, ${ }^{129}$ where defamatory matter was sent by telegram from England to Scotland; Evans v. Stein, ${ }^{130}$ where defamatory matter was sent by telegram from Scotland to England. None of these cases expressly states that the locus delicti is determined by the place where loss is suffered, but it is submitted that the remarks made ${ }^{131}$ can refer only to the third element of a tort, namely, resultant damage. The second view, where emphasis is placed more on the place where damage results than on the place from which the harm ensues, has found more favour in Scottish decisions than in English. Even in Scotland, however, there is authority to the effect that the place of harm should not be conclusive of the locus delicti: ${ }^{182}$

It seems to me . . . that in ascertaining the locus delicti regard must be had not only to the place where the person of the woman was finally surrendered but also to the place where the preliminary steps were taken by the wrongdoer, and where ho practiced the acts and wiles whereby he fraudulently captured the woman's affections.

Neither of these two solutions is completely satisfactory. The first suffers from the defect that a tort will not normally be complete until such time as damage is suffered. It seems inconsistent to talk of the locus delicti where a tort, in its complete sense, has not been committed. The second solution is too mechanical in attaching the locus delicti to the place where harm occurs. ${ }^{138}$ Some realisation of the difficulties and an attempt to reconcile them is found in the Privy Council decision in Distillers Co. Ltd? v. Thompson, ${ }^{134}$ where both theories were considered in a review of the relevant authorities. In that case, the first defendants manufactured in England a drug named "Distival", which was sold to the second defendant in New South Wales. The mother of the plaintiff took the drug in 1961 and the plaintiff was born with deformities in 1962. The plaintiff brought an action in negligence claiming that her mother had taken Distival during her pregnancy; that the drug thalidomide had a harmful effect on the foetus of an unborn child during the first three months of pregnancy and that as a result she was born malformed and with defective vision. The point at issue was whether or not the claim was a "cause of action which arises within the jurisdiction".185 In other words, the court was faced with the task of deciding what was the locus delicti of the alleged tort. Lord Pearson outlined three possible theories which could be used to decide the point in issue: ${ }^{136}$

(i) every part of the cause of action must have occurred within the jurisdiction. Relying heavily on the decision in Jackson v. Spittall ${ }^{137}$ and on the fact that

126 Supra, n. 120.

127 Supra, n. 121.

128 [1865] Sess. Cas. 1049 (3M.).

129 [1910] 2 Scots L.T. 442.

130 [1904] Sess. Cas. 65.

131 In all these cases, the locus delicti was said to be Scotland since the harm took effect there.

182 Soutar v. Peters [1912] 1 Scots. L.T. 111.

133 The introduction of vicarious liability would create havoc with such a mechanical formula.

134 Supra, n. 119.

135 Within the meaning of the words of the Common Law Procedure Act 1899 s. 18(4) (New South Wales).

136 Supra, n. 119 at 698.

137 ( 1870 ) L.R. 5 C.P. 542. 
the theory was "too restrictive for the needs of modern times", his Lordship rejected this theory.

(ii) the last ingredient must have occurred within the jurisdiction. Lord Pearson was concerned that the last event should not always be conclusive, and in support of his argument he cites as an example, a woman who purchases a drug in one place, consumes it in another place and damage is caused there. The woman then returns to the original place of purchase. In this kind of case, Lord Pearson rejects the approach of asking where the tort was complete, that is, where damage was suffered. Rather, he suggests, the court should look back on the events and ask: "where in substance did this cause of action arise?"138 To accept this second theory, he implies, would be to attribute too great a weight to the place where harm is suffered.

(iii) the act on the part of the defendant which gives the plaintiff his cause of action, must have occurred within the jurisdiction.

This approach, he states, is inherently reasonable and well-supported by authority. He does, however, point out the difficulties involved where the negligent act and the resultant damage are separated in time and place. He unfortunately found it unnecessary to express an opinion on that point. ${ }^{139}$ In the present case, the court found that the negligence consisted in failure to give a warning as to the dangers of the drug. That notice could have been given in England or in New South Wales, but the plaintiff was entitled to complain of a lack of notice in New South Wales, and, therefore, a cause of action did arise in New South Wales, where the action was brought.

One writer has suggested that the decision in Thompson v. Distillers Co. ${ }^{140}$ does not resolve the issue where the breach of duty and the resultant harm take place in different jurisdictions. At least by discounting the test laid down in Monro, ${ }^{141}$ the case came to a reasonable conclusion, although the test of "the place where damage occurs" must now be viewed in a less strict light than it was before.

Now this identification of the locus delicti is inherent in an application of the traditional rules, where both the lex loci delicti and the lex fori must be specifically identified. However, none of the theories advanced above adequately canvasses the multi-jurisdictional case, where duty, breach and resultant harm arise in different jurisdictions, or where preliminary actions and resultant harm are spread over several jurisdictional units. The emphasis given to the locus delicti will be discussed later. It is sufficient, at present, to outline the difficulties encountered in identifying the locus delicti.

There is a second threshold question which must be answered before the traditional rules may be discussed adequately. It has been suggested ${ }^{142}$ that the first limb of the rule in Phillips v. Eyre ${ }^{143}$ relates to jurisdiction rather than choice of law, and that being the case, it does not follow that the forum must always apply the lex fori to the issue before the court. This suggestion, first made by Yntema ${ }^{144}$ was that, as regards the first limb of the rule, it would not be reasonable to construe the rule as anything more than a threshold requirement

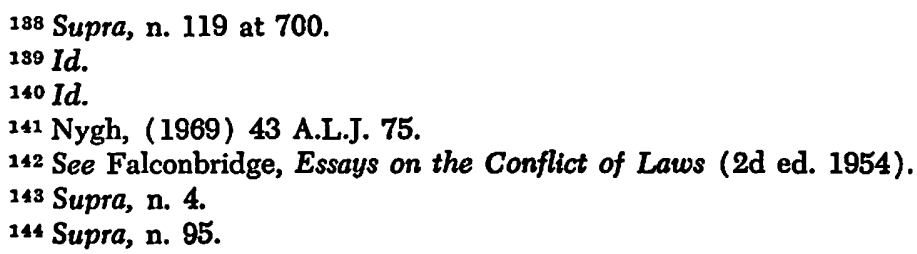


that a suit on a foreign wrong must be such as to be triable in England. He argues that this would exclude an action based on trespass to foreign land, for example. The argument has been taken up and amplified, with a full review of the relevant authorities, by Gerber. ${ }^{145}$ The latter writer argues that the only authority supporting the lex fori as the chosen law is The Halley, ${ }^{146}$ which case, he contends, does not support that proposition under close scrutiny. Gerber argues that the basis of the decision in that case was not that the act was not tortious by the lex fori, but that the provision of a forum in those circumstances would constitute a violation of English public policy. He then goes on to show how subsequent cases have adopted the approach taken in The Halley, ${ }^{147}$ and how this emphasis, in his opinion, is incorrectly placed.

Two statements, in particular, which Gerber found it imperative to rationalise, appear to be somewhat incontestable. The first is that of Lord Justice Selwyn, in The Halley: ${ }^{148}$

But in these and similar cases the English Court admits the proof of the foreign law as part of the circumstances attending the execution of the contract, or as one of the facts upon which the existence of the tort ... may depend, and it then applies and enforces its own law so far as it is applicable to the case thus established . . . .

The second statement is that of Windeyer J. in Anderson v. Eric Anderson Radio of T.V., ${ }^{149}$ where His Honour recognised the argument regarding the first rule in Phillips v. Eyre, ${ }^{150}$ but preferred to base his view on judicial authority rather than "professorial dicta". Referring to a previous decision of the same court, he stated: 151

. when in Koop v. Bebb this court spoke of the rule of private international law which defines the conditions of civil liability' in one state for an act done in another, the reference was not, as I read the judgment, merely to the entertaining of an action but also to the substantive law for determining liability in an action.

Since Gerber expressed these views, there has been further judicial authority of the highest order, which would appear to weigh heavily against his contentions. When the case of Chaplin v. Boys ${ }^{152}$ came before the House of Lords, the opportunity was taken for a full review of the traditional rules, and in the course of that review several statements were made concerning the first part of the rule in Phillips v. Eyre. ${ }^{153}$ Lord Wilberforce examined the first limb and concluded: ${ }^{154}$

I accept what I believe to be the orthodox judicial view that the first part of the rule is laying down, not a test of jurisdiction, but what we now call a rule of choice of law. . . .

Lord Pearson ${ }^{155}$ reiterated the same sentiments, when he said:

In my opinion, it was right for the learned judge at the trial to apply the English substantive law, being the lex fori, in accordance with the established rule. . . .

It is submitted that these statements are correct, and being of high authority and recent date, should be accepted as statements of the true nature of the first limb of the rule in Phillips v. Eyre. ${ }^{156}$ The writer shares some of the sentiments

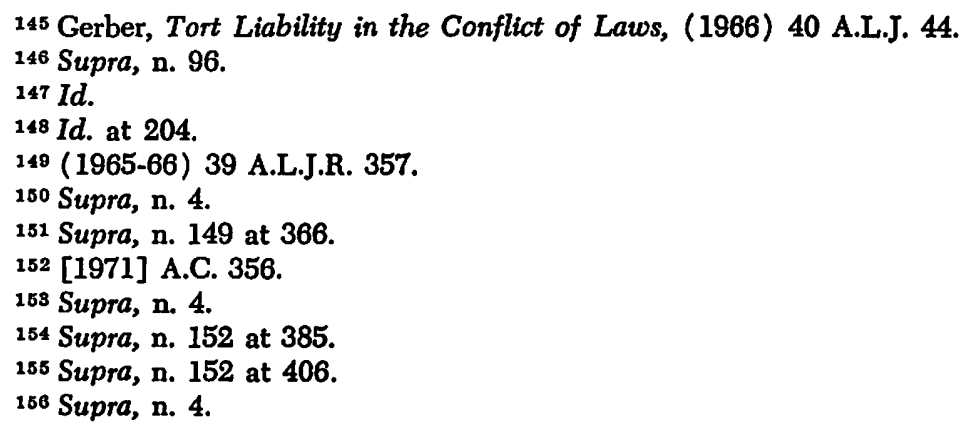


expressed by Gerber, ${ }^{167}$ but it is submitted that Gerber's desire for some flexibility in the traditional rules cannot be attained by an assertion that the first limb of the traditional rules, goes to jurisdiction and not choice of law.

\section{The Traditional Rules Criticized}

The rule in Phillips v. Eyre, then, can be taken as representative of the traditional rules, and stated as follows: ${ }^{158}$

An act done in a foreign country is a tort and actionable as such in England, only if it is both (i) actionable as a tort according to English law; (ii) not justifiable, according to the law of the country where it was done.

It should be noticed that the rule contains the appendage added by the decision in Machado v. Fontes, ${ }^{150}$ namely the requirement that the act be "not justifiable" in the locus delicti rather than actionable as a tort there, and that decision, despite being attacked, defended, criticized, overruled in England, ${ }^{160}$ remains an authority in Canada today. ${ }^{161}$

It is quite apparent that these rules place the lex fori in a most strategic position. Subject to a somewhat vague proviso that the acts complained of possess some kind of wrongful character according to the lex loci delicti, it is left to the lex fori to govern all other substantive issues. The same criticism may be directed to this emphasis as that directed earlier, ${ }^{162}$ to the forum-bias in a "policy-evaluation" approach. The only difference is that the latter concealed the bias by erecting an "interest worthy of protection", whereas the bias of the former is quite patent.

Such a prejudice in favour of the lex fori is inconsistent with three of the "interests" mentioned earlier in relation to "choice of law policy", as being worthy of protection by conflicts rules.

(a) It was stated that the locus delicti had a valid interest in controlling and regulating conduct which took place within that locus. It was also stated that the lex fori should not be forced to give remedies in situations where this would be contrary to the public policy or morality of the forum. At first sight, neither of these "interests" appears to justify the controlling influence which the lex fori assumes.

A hypothetical situation might profitably be considered:

$A$ and $B$ are close neighbours in Scotland, and are quite prominent in their community. B is of German origin and was involved, to some extent, with the Nazi party in the 1930's. A communicates this fact to various people and this has a damaging effect on B's social status in the community. Both parties move to England, where $B$, in view of the damage to his reputation, decides to bring an action against $A$. In England there is no recognised tort heading under which the action might be classified, and the action would not clear the first hurdle of the rules, that the conduct be actionable as a tort by the lex fori. ${ }^{103}$ The mere fact that $B$ brought his action in a forum which, after the event proved to be a mutual forum for plaintiff and defendant, deprived him of his remedy altogether. The important role played by the lex fori in such a situation must be seriously questioned. It cannot be said that there was an interest in regulating wrongful conduct

157 Supra, n. 145.

158 Supra, n. 4 at 28.

150 Supra, n. 88.

160 One consensus reached in the decision in Boys v. Chaplin, supra, n. 152, was that Machado v. Fontes should be overruled.

161 Gronlund v. Hansen, supra, n. 80 at 440.

162 See II. Choice of Law Policy.

163 That is, the first part of the rule in Phillips v. Eyre, supra, n. 4. 
within that locus since the acts complained of, in the example given, took place entirely outside of and were totally unrelated to the forum. The only possible justification would be that the forum cannot countenance allowing a claim which does not exist under its own law. ${ }^{164}$ It seems rather inconsistent that the law of a place entirely unrelated to the events in question should be invoked to determine the nature of those events. If a certain law is applied, it ought to be a law which bears some realistic relationship to the events and the parties involved. The purpose of conflicts rules is to provide a choice of law rule which enables the court to determine which law has the closest connection to the events and the parties and which, therefore, should regulate those events. The first part of the rule in Phillips v. Eyre has a built-in provision for the regulation of events by a law which may have little or no connection with the acts in question.

(b) Not only do the rules provide for the situation mentioned above, they also allow the plaintiff to choose whichever forum of those available is most convenient for him. Such a situation would not be bad per se if it were not for the fact that the applicable law may vary with whichever forum is chosen. In other words, there is the possibility of blatant forum-shopping. The second part of the rule does nothing to circumvent this change either. Once an act is characterised as "wrongful" in the locus delicti, be it criminal, tortious, or merely wrongful, the plaintiff may choose the forum which is most favourable to him. ${ }^{105}$ The most obvious example of such an injustice is the case of Machado v. Fontes. ${ }^{108}$ There the act complained of was clearly wrongful, criminally sanctioned, in the place of acting, but did not give rise to civil remedies. By selecting English law as the lex fori, the plaintiff was able to recover damages which would not have been available to him in the place of the crime. It has already been pointed out that this will work a great deal more injustice to the defendant than the plaintiff. The liability of the defendant being fixed irrevocably, he is permanently saddled with such liability. A similar situation would arise where the heads of damage varied between different countries. If Scotland applied the English conflicts rules in respect of an automobile accident in England, a plaintiff might be able to select Scotland as a forum, and thereby include in his damages a claim for solatium as an element of damages. ${ }^{167}$

Since it is true that the plaintiff cannot take advantage of a foreign law in order to enhance his cause, then why is he permitted to do just that by choosing an appropriate forum, the law of which he wished to be applied? Conflicts rules purport to remove, as far as is possible, the inconsistent results of each country applying its own law and no other. Does this mean that the rules in Phillips v. Eyre ${ }^{108}$ are a throw-back to the days of strict sovereignty theories, in which each forum applies its own law? The rules can hardly be reconciled with even the vested rights theory, since the seat of the obligation, on that basis, would be the

164 It would be quite reasonable for the court to deny recognition or enforcement of something which was contrary to the public policy or morality of the forum. See e.g., Regazzoni v. Sethia, supra, n. 74, where the English courts refused to recognise a partnership, the main purpose of which was to derive profit from the commission of a criminal offence in a foreign country.

165 Provided that the court has jurisdiction over the defendant or is prepared to give leave to serve ex juris.

168 Supra, n. 88.

${ }^{107}$ Scots law, heing the lex fori, would settle the heads of damages by its own law. This was not the case in McElroy v. McAllister, supra, n. 66, where the Scottish emphasis on the lex delicti denied the pursuer a right to claim any damages under the head of solatium.

168 Supra, n. 4. 
locus delicti, whereas Phillips v. Eyre ${ }^{189}$ gives control to the lex fori.

(c) The "reasonable man" concept, which is widely used and well-accepted in the common law of torts, does not seem to have been canvassed very widely in torts in the conflict of laws. In the case of Machado v. Fontes, ${ }^{170}$ it might have been possible to construct some sort of expectation in the minds of the parties, that their actions should be regulated by the law of Brazil. If the plaintiff is free to choose what law is to be applied by selecting a forum, ${ }^{171}$ then whatever expectations may have been raised in the minds of the parties, are ruled out. The reasonable man would expect that a tort action concerning a nuisance caused by the emission of noxious odours, litigated between parties resident, domiciled and working in area X, should be governed by the law of area $\mathrm{X}$, but under the traditional rules, the applicable law could be the law of area $\mathrm{Y}$ or $\mathrm{Z}$, provided these places would assume jurisdiction. In such a situation, the result would be highly unpredictable, the applicable law subject to the whim of the plaintiff, and the basis of conflicts rules destroyed.

It would not be fair to leave the critique at this point, since some attempt, albeit historical, should be made in order to explain why the traditional rules exist in their present form, and the lex fori plays such an important role. These rules were enunciated at a stage in jurisprudential thought when the sovereignty theory carried considerable weight. Such a theory presented an obstacle to admitting a foreign law and it is not too difficult to see why a judiciary, in this frame of mind, should be reluctant to allow a law, other than that of the forum, to regulate a case brought in that forum. Hancock expresses the aura surrounding the birth of the rules in this fashion - in the 1860's the idea of enforcing a foreign law was novel, and the impression among judges was that such an application of a foreign law would be a daring innovation. He continues: ${ }^{122}$

But in the cooperative atmosphere of modern conflict of laws, the first rule in Phillips v. Eyre is like a breath from a bygone age. As a restriction upon the normal application of choice-of-law principles and the realisation of choice-of-law policies it is objectionable in its generality.

The rule, then, was given birth to at a time when "forum-bias" was most marked. Moreover, it served another purpose, namely, to insulate English common law against all foreign elements which differed from it. The same attitude can be traced in other fields, most markedly in the area of recognition of polygamous and potentially polygamous marriages. ${ }^{173}$

169 Id.

170 Supra, n. 88.

171 This possibility depends on whether the first rule in Phillips v. Eyre is classified as a rule of jurisdiction or a rule of choice of law. The writer has already concluded that the rule relates to choice of law, thus allowing the plaintiff some freedom in his choice of forum.

172 Hancock, supra, n. 57 at 87.

178 The statement of Lord Penzance in Hyde v. Hyde (1866) L.R. 1 P. \& D. 130 at 138 to the effect that a polygamous marriage should be virtually ignored by the law of England has now been relaxed so that such a marriage may be recognised for certain limited purposes. See e.g., list of purposes: Power on Divorce (2d ed. 1964) lists these rules as follows:

(1) The parties to a polygamous marriage cannot avail themselves of the matrimonial machinery of the Canadian courts in respect of that marriage.

(2) A polygamous marriage is not a valid first marriage for the purpose of founding a prosecution for bigamy. 
Taken to an extreme, such a view is tantamount to saying that anything different is bad. Basic common sense and experience ought to reject such an attitude. Hancock succinctly rejects such an approach: ${ }^{174}$

But it can scarcely be contended that every tort liability unknown to English law, is, from the standpoint of English law, something so immoral, that it ought not to be recognised.

Common law courts are prepared to enforce laws regulating foreign exchange, ${ }^{175}$ among other things, which differ from the laws of the forum. Why, then, should torts law be singled out for such differential treatment? If the traditional rules were formulated to protect the lex fori from foreign intrusions, then it is submitted that this would be better done by the courts making use of the same concept used in other areas, namely, public policy. If this is the purpose, Hancock's view ${ }^{176}$ is that: ${ }^{177}$

[T] he cases in which the foreign law is so unfair and oppressive that choice-of-law policies are opposed to English ideas of justice, will probably be few and far between. And when a case of this type does occur, the courts could easily deal with it under their general discretionary power to reject any foreign law which clashes with the public policy of the forum.

At the crux of this value judgment is a failure to distinguish between a mere difference in the law and a head-on collision of policies. It is quite conceivable that two jurisdictions might adopt two different approaches while attempting to effect the same policy, for example, no-fault automobile insurance. It would in no way harm the forum if, in that case involving the foreign element, the foreign law were applied. Cardozo J., struck at this restrictive attitude: ${ }^{178}$

We are not so provincial as to say that every solution of a problem is wrong because we deal with it otherwise at home.

(3) A polygamous marriage will bar either party thereto from subsequently contracting a valid monogamous marriage in Canada.

(4) The issue of a polygamous union will be recognised as legitimate where the status of legitimacy is conferred under the law of the father's domicile.

(5) A polygamous marriage may be recognised as valid for the purpose of determining the succession rights of widow(s) or widower(s).

(6) The courts will recognise polygamous unions as valid for the purpose of applying such rules of law as are based upon the doctrine of marital unity.

Characterization of marriage: The question whether a marriage is monogamous or polygamous is exclusively referable to the lex loci celebrationis. Cf. also: Iman Din v. National Assistance Board [1967] 2 Q.B. 213, where a husband was ordered to reimburse the National Assistance Board in respect of monies paid by the Board to his wife, with Sowa v. Sowa [1961] P. 76, where a party to a polygamous marriage was not entitled to the relief given by the courts in the exercise of matrimonial jurisdiction.

174 Supra, n. 57 at 87.

175 Zwnostenka Banka v. Freeman [1950] A.C. 57.

176 Supra, n. 57 at 88 .

177 See e.g., Peter Buchanan Ltd. \& McHarg v. McVey [1955] A.C. 516 and Grell v. Levy (1864) 16 C.B.N.S. 73.

178 Loucks v. Standard Oil Co. (1918) 224 N.Y. 99 at 111. 
In some areas the courts have freed themselves from the bonds of this restrictive attitude. Fiscal laws are recognised provided they do not involve the collection of money, ${ }^{179}$ extra-judicial divorces have been recognised, ${ }^{180}$ and polygamous marriages have been recognised for various purposes. ${ }^{181}$ Yet, in the law of torts, the mode of progress is still by "mechanical jurisprudence, blind adherence to a verbal formula without any regard for policies or consequences" ${ }^{182}$

It is submitted that the two basic reasons for the existence of the rule in Phillips v. Eyre ${ }^{183}$ are either obsolete or could best be accommodated in another manner. The fear of enforcing a foreign law no longer exists. That notion is obsolete and the need to protect the public policies of the forum should be satisfied by an appropriate resort to the right to reject if an application of foreign law would be contrary to public policy. Conservatism should not be the basis for retention of Phillips v. Eyre. ${ }^{184}$

It would appear, in addition, that the field of torts has been singled out in another way, in that two hurdles must be crossed before a tort action can be successful. According to the vested rights theory, one test, and only one test, must be satisfied - the right must be validly acquired by the law of the place of origin of the right. One might expect, therefore, that if the locus delicti were chosen as the place of origin, then, provided the right was validly acquired there, a tort action could be successfully litigated anywhere. However, this does not appear to be the case. The right must be validly acquired, not only by the lex loci delicti, but also by the lex fori. In another area where such a double test was applied, the rule has recently been subject to a considerable degree of criticism. The English Adoption Act, 1958, ${ }^{185}$ regulated domestic adoptions and conflicts rules were fashioned on the basis of the safeguards provided therein. These were:

(i) The applicant must be domiciled in England.

(ii) Both applicant and child should be resident there.

When these rules were considered by the Court of Appeal, ${ }^{186}$ a very strong dissent was expressed by Lord Justice Salmon, ${ }^{187}$ that, provided a foreign law prescribed similar safeguards to those of the forum, the adoption should be recognised. In his view, the double test of domicile and residence was punitive. The only other area where such a double test applies, apart from the requirement in respect of the public policy of the forum, is the field of torts. It is submitted that this requirement could profitably be removed.

One would expect the development of the rule in torts to proceed by way of the locus delicti, but even this presents difficulties. Such a development has taken place in the United States, and can be seen embodied in the First Restatement ${ }^{188}$ - the law of the place of the wrong governs. It is, however, in the United States that this simple mechanical rule has proved most unsatisfactory. It has been realised that the locus delicti may have merely casual or fortuitous connection with the tort, and this problem was made very clear in the cases of

170 Regazzoni v. Sethia [1956] 2 Q.B. 490 at 515 per Denning L.J.

180 See e.g., Russ v. Russ [1964] P. 315.

181 Supra, n. 173.

182 Hancock, supra, n. 57 at 89.

183 Supra, n. 4.

184 Id.

185 Adoption Act 7 Eliz. 2, c. 5.

${ }^{180} \mathrm{Re}$ Valentine's Settlement [1965] Ch. 831.

187 Id. at $852,853$.

${ }^{188}$ American Law Institute, Restatement of the Law of Conflict of Laws (1934). 
Babcock v. Jackson ${ }^{180}$ and Kilberg v. North East Airlines. ${ }^{190}$ As a result, jurists and judges have sought some substitute for this simple but limited rule. Having been weighed in the balances and found wanting, the "place of wrong" rule has succumbed to the "proper law" of the tort.

\section{THE PROPER LAW OF A TORT}

In conflict of laws, there is a constant striving to reach a via media between simple clear and workable rules, on the one hand, and on the other, decisions which reflect a degree of justice between the parties to the action and fairness to the laws which might be applicable to the question. The suggestion that the applicable rule should be that of the "proper law" of the tort has been supported eagerly, ${ }^{191}$ cogently argued, ${ }^{192}$ stigmatised, ${ }^{193}$ treated with disinterest, ${ }^{194}$ and dismissed as inapplicable. ${ }^{195}$ The first suggestion ${ }^{106}$ that a "proper law" should be applied was greeted with the utmost criticism and contempt. ${ }^{197}$ Twenty years later, the courts of Common Law jurisdictions, despite their recognition of the inadequacy of the present rules, are hesitant to accept this doctrine. ${ }^{193}$

The criticism most often heard is that the degree of flexibility introduced by the "proper law" doctrine is too great, that the law would then become uncertain, and that the simple, predictable, yet inadequate traditional rules are preferable to such an innovation. To adopt such an attitude, however, is to ignore the developments which have taken place in other areas of the law, and which have a bearing upon the validity and practicality of the "proper law" doctrine. Arguing from the analogy of the law of contract, Morris, who was probably the first jurist to propound the "proper law" theory in the field of torts, states his position as follows: ${ }^{190}$

The object of this paper is, however, not to argue the merits of the English proper law doctrine as applied to contracts, but to suggest that there is room for a similar approach in the field of torts.

In support of this "proper law" doctrine, Morris adduces several cogent arguments. First, such a doctrine will introduce a sufficient degree of flexibility so that courts may take account of the varying factors in any one case. It is difficult to see why the same degree of significance should be accorded to the various points of contact such as lex loci delicti, or lex fori, when the relevance of these factors to the case at bar, may vary widely in any given case. Two examples may be of help to illustrate this point:

(i) A and a friend, B, drive out one evening to watch a sporting event. Inadvertently they take a wrong turning and are forced to make a detour which causes them to cross into another jurisdiction. During this detour the car collides with the parapet wall of a bridge.

180 Supra, n. 49.

190 Supra, n. 79.

191 See e.g., the judgment of Lord Denning in the Court of Appeal in Boys v. Chaplin, supra, n. 3 at 20.

192 Morris, supra, n. 76.

193 Boys v. Chaplin, supra, n. 152 at 383 per Lord Donovan:

I do not think we should adopt any such doctrine as 'the proper law of the tort' with all its uncertainties. There is no need here for such a doctrine - at least while we remain a United Kingdom.

194 Gronlund v. Hansen, supra, n. 80, where the British Columbia Court of Appeal completely ignored the application of a "proper law" concept by the trial judge.

195 Supra, n. 152 at 381 per Lord Guest.

196 Supra, n. 76.

197 See e.g., Gow, Delict and Private International Law, (1949) 65 L.Q.R. 313 at 316.

198 Supra, n. 152, n. 80.

109 Supra, n. 76 at 883. 
(ii) A books a return ticket on a flight from his home in country $\mathrm{X}$ to country $\mathrm{Y}$ on an aeroplane owned by B Incorporated (which company is incorporated in country $X)$. On the flight $A$ is served some food from which he contracts food poisoning. During his stay in country $\mathrm{Y}, \mathrm{A}$ initiates an action against the airline company which has a branch office in country $Y$.

Each of these examples discloses how much the significance to be attached to the lex loci delicti and the lex fori may vary. In the first example, the place of the wrong is quite fortuitous and quite unforeseen by the parties. Apart from the fact that the accident occurred in that place, the place of the wrong has not the slightest connection with a possible tort action between the occupants of the car. Moreover, if the rules in issue concerned the possibility of tort actions between host and gratuitous passenger, it is arguable that the lex loci delicti should in no way regulate the possibility of such an action. In the second example, the converse is true. The choice of forum would appear to have as little connection with the tort as did the locus delicti in the first example.

According to the traditional rules, the test is quite inflexible - actionability by the lex fori and lack of justification by the lex loci delicti. The "proper law" doctrine, on the other hand, gives the court an opportunity to assess the relative importance to be attached to the locus delicti and the lex fori. If the facts in the first example were altered slightly, it is possible that the major issue would not be the casuality of the locus delicti, nor the policy of the forum, but the issue of guest-host tort actions, which, conceivably should be regulated by the law in connection with which the relationship was formed. The traditional rules could take no cognisance of this latter factor, whereas the "proper law" doctrine could consider such a factor.

Furthermore, a "proper law" approach permits the court to consider not merely a tort in general, but the very species of tort which is involved. In other words, the "proper law" would allow the courts to establish more specific rules to govern particular torts, rather than force them to attempt to formulate a general rule to cover the whole field of tort law. ${ }^{200}$

The list of particular torts as opposed to the general law of tort would appear almost to be open-ended, and within such a list might appear such torts as defamation, conspiracy to injure, inducing breach of contract, seduction, negligence, liability for the escape of dangerous substances, liability for the escape of animals, and many others. Unlike the conflicts rules for contracts, the proponents of the traditional rules would apply an all-embracing rule to each of these particular torts, but, as Morris suggests, it is unlikely that socially desirable results can be achieved by applying the same conflicts rule to each tort, since the categories of torts differ so widely, and it would be prudent to apply a rule that would be sufficiently flexible to encompass all the various factors.

Neither the traditional rules nor the "place of wrong" doctrine (as applied in the United States) is adequate to deal with the problems created by vicarious liability for tortious acts. Under either of these doctrines it would be inequitable, for example, to impose liability upon the owners of motor vehicles "for loss or damage sustained by any person by reason of negligence in the operation of the motor vehicle on a highway unless the motor vehicle was without the owner's consent, in the possession of some person other than the owner or his chauffeur"201 merely because that happened to be the rule in the locus delicti or the forum where the case was heard. However, since neither of these doctrines provide for

200 This approach has been adopted in the Restatement (Second) Conflict of Laws, where the general rule is broken down into specific torts.

201 Highway Traffic Act R.S.O. 1960, c. 172 as amended S.O. 1966, c. 64. 
any flexibility in the application of the rule, tortuous arguments and devious reasoning may have to be resorted to in order to give justice in a particular case.

Finally, Morris argues that the application of the "proper law" would make it possible to break the problems down into smaller units, thus localizing and pointing out the issues at stake. He gives examples of questions which might arise: ${ }^{202}$

Is the infliction of harm actionable without proof of negligence or intent? Is the plaintiff's contributory negligence a defence? Does the fellow-servant rule bar recovery? Was the person causing the harm a servant or an independent contractor? Is the bailor of a car liable for the negligence of his bailee? Is it tortious to cause the death of a human being? If so, who can sue and among whom should the damages be distributed? Does the cause of action survive the death of the tortfeasor or the injured party? Can a wife sue her husband in tort? Is a husband liable for his wife's torts?

Justice cannot be served, it is submitted, simply by applying either the lex loci delicti or the lex fori to questions such as those posed above. Under the "proper law" doctrine, a court would be in a better position to segregate such issues and to provide a more just solution to the specific problem as it arises between the parties.

For the reasons given, justice could better be served by the adoption of the "proper law" doctrine than by adherence to the old rules. The ever changing circumstances of the modern world demand a flexible test and a rational approach to problems that present themselves. The field of torts is sufficiently diverse to warrant different treatment of the various categories of torts.

It is possible then, to argue by analogy, that the "proper law" doctrine should be accepted in torts as well as in contracts. The decision-making process involved in the determination of what is the "proper law" has been established and developed in contract law and the law relating to recognition of foreign decrees of divorce. It is possible, it is submitted, to operate by way of this same process in torts law too. Any suggestion of a "proper law" approach immediately encounters the criticism that its adoption would introduce grave uncertainty into the law, that each decision would be merely a subjective opinion based on vague ideas of "connection" and "interest". It is submitted, however, that this will not be the case. What were previously rules, need not be abandoned entirely, thus losing all significance, but should be relegated to the level of other possible "interests" with which they should compete for priority. The locus delicti and the forum will still be of great significance in the majority of cases, but the "proper law" doctrine makes it possible for them both to be replaced where the circumstances are appropriate. On this basis a different decision would have been reached in the case of Mackinnon v. Iberia Shipping Co. ${ }^{203}$ In that case, a tort was committed on board ship flying a British flag, while the ship was within the territorial waters of San Domingo. Under the double test, the plaintiff was denied a remedy because the particular tort which he averred was not recognised by the law of San Domingo (lex loci delicti). In this typical case, no "grave uncertainty" would be introduced merely by replacing the lex loci delicti with the "law of the flag", which, in the circumstances, stood out as the obvious law to be applied.

\section{A PROPER LAW APPROACH IN OTHER AREAS}

\section{The Proper Law of Contract}

It has been a point of argument and discussion that the "proper law" approach used in contract cases should be adopted in tort law, and it is appropriate, 
therefore, to consider the similarities that exist in the questions that must be asked and the mode of approach that must be adopted in contract cases.

Two factors suggest themselves as being closely connected with a contract, and therefore as being valuable in regulating it. These are the lex loci contractus and the lex loci solutionis. A leading case on the former is $P$. \& $O$. Steamship Navigation Co. v. Shand ${ }^{204}$ where Shand in London, booked a passage with P. \& O. from Southampton to Mauritius, the journey to be undertaken in three stages: (a) by ship from Southhampton to Alexandria; (b) by road from Alexandria to Suez; (c) by ship from Suez to Mauritius. French law prevailed in Mauritius, and the ticket contained a clause limiting liability for loss of luggage, which clause was valid by English law but not by French law. Some of Shand's luggage was lost in the water at Suez and he sued P. \& O. in Mauritius. The Privy Council, reversing the previous decision, held that the claim must fail, since the locus contractus was English and that law should govern the contract.20s Such a strict rule would be unsatisfactory if, for instance, the ticket had been bought by an Irishman, in Norway, for a similar journey.

A leading case applying the lex loci solutionis is Chatenay v. Brazilian Submarine Telegraph Company. ${ }^{206}$ Chatenay lived in Brazil and granted a power of attorney to B., a London stock broker, for the sale of certain stocks. The power was drawn in the Portuguese language and form, and was signed in Brazil. B. sold the shares, but absconded with the proceeds, and Chatenay therefore brought an action for rectification of the register. The case turned on the validity of the power of attorney and the court held that, although made in Brazil, the power was to be exercised and acted upon entirely in England and that English law governed its validity.

That decision would appear to be a perfectly reasonable one. In other circumstances, however, the lex loci solutionis might have as little connection as the lex loci contractus in the hypothetical example given above. In a commercial contract between A and B, both Saskatchewan businessmen for the purchase and sale of farm machinery f.o.b. Winnipeg, the place of performance, Manitoba, would have relatively little significance.

Various other laws have been suggested as capable of application to contracts - the law of the flag in Maritime contracts; ${ }^{207}$ the most effective law; ${ }^{208}$ the lex situs for immoveables; ${ }^{200}$ and the law of the place of practice for professional persons. ${ }^{210}$

It is obvious that with so many specific rules, the application of any one might work injustice in circumstances where it is not appropriate. It was this situation which brought about the search for new rules for contracts in conflict of laws. The bases varied in different countries - in the European countries ${ }^{211}$ there was a preference for party autonomy thus allowing the parties to choose the law to be applied. In the United States, the early view was that the intention of the parties, in making a contract, should be recognised. However, the place the parties had in mind was soon replaced by "the law of the place

204 (1865) 3 Moo. P.C.N.S. 272.

205 Id.

200 [1891] 1 Q.B. 79.

207 Lloyd v. Guibert (1865) L.R. 1 Q.B. 115.

208 In re Missouri S.S. Co. (1889) 42 Ch.D. 321.

${ }^{209}$ In almost all cases the lex situs is presumed to be the applicable law. An exception to this general rule was BSA Co. v. DeBeers [1910] 2 Ch. 502, where a contract in respect of a mortgage over land in another country was found to be an "English contract" as between the parties.

210 R. v. Doutre (1884) 9 A.C. 745.

211 See Anton, supra, n. 28 at 187, 188. 
where the contract was made". This basic rule was carried into the Restatement, ${ }^{212}$ with a slight modification. There was some pressure that the place of performance should be recognised and the rule enunciated by Beale allowed for this alteration. The basic rule was that the lex locus contractus should apply except to matters of performance, when the lex loci solutionis applied. In England and the other Common Law countries, the rule chosen was that the "proper law" of the contract, or the lex causae should be applied, on the basis that, although a contract may have connections with different systems of law, each contract centres around and has a closer connection with one particular law than with any other law, and this is the "proper law". In other words, the "proper law" is the centre of gravity of the contract and it is, in vested rights terms, the origin of the rights and obligations of the parties. Cheshire describes the need for such a general rule thus: ${ }^{213}$

The 'proper law' of a contract is a convenient and succinct expression to describe the law that governs many of the matters affecting a contract. It has been defined as that law which the English or other court is to apply in determining the obligations under the contract'. However ascertained ... it consists of a single legal system, but it is essential to appreciate at the outset that not all matters affecting a contract are necessarily governed by one law. The correct enquiry is not - what law governs a contract? It is - what law governs the particular question raised in the instant proceedings? "The fact that one aspect of a contract is to be governed by the law of one country does not necessarily mean that that law is to be the proper law of the contract as a whole, and the circumstances sometimes require different questions to be submitted to different laws'.

That the rule is so general can be seen from the various definitions that have been given. Lord Denning defines the "proper law" thus: ${ }^{214}$

The 'proper law' of a contract depends not so much on the place where it is made, not even on the intention of the parties or on the place where it is to be performed, but on the place with which it has the most substantial connection.

Lord Simonds stated his view thus: ${ }^{215}$

It is "the system of law by reference to which the contract was made or that with which the contract has its closest connection'.

Wynn-Parry J. would define the "proper law" as the law with which the parties either expressly or impliedly have chosen to govern their contractual relations. ${ }^{216}$ The point of dispute in these definitions comes down to the question of whether the determination of the "proper law" should be based on the subjective intention of the parties, (the view of Wynn-Parry J.) or upon the objective consideration of the facts and circumstances (the view of Lord Denning). This in turn raises the question that arose in Vita Food Products v. Unus Shipping Co. Ltd. ${ }^{217}$ There, a Newfoundland statute provided that the Hague rules should govern any contract of carriage from that country and that every Bill of Lading in respect of such carriage should contain an express clause making the Rules applicable. In the instant case, an old form of Bill of Lading was used which did not provide for the application of the Hague rules. Nevertheless, the Bill contained much the same provisions in that the owners were not to be liable for negligent navigation. There was an agreed express choice of English law in the Bill. The ship ran ashore in Nova Scotia due to negligent navigation. The Canadian courts adopted

212 American Law Institute, supra, n. 188 at s. 311 (1934). This position has, however, been altered in the proposed official draft of the Restatement Second (s.187) which brings the rule into line with that expounded by the Privy Council in Vita Food Products.

218 Cheshire, Private International Law 197, 198 (8th ed. 1970).

214 Boissevain v. Weil [1949] 1 K.B. 482, on appeal [1950] A.C. 327 per Lord Denning. 215 Bonython v. Commonwealth of Australia [1951] A.C. 201 per Lord Simonds.

216 In re United Railways of Havanna [1958] Ch. 724 at 756.

217 [1939] A.C. 277. 
an objective approach throughout. ${ }^{218}$ The Privy Council, ${ }^{210}$ however, based its decision entirely upon the choice of English law by the parties, by which the same result was achieved in that the Bill of Lading excluded liability. Lord Wright, giving the judgment of the court, commented on the choice of the "proper law" by the parties: ${ }^{220}$

In their Lordships' opinion the express words of the bill of lading must receive effect, with the result that the contract is governed by English law .... But where the English rule that intention is the test applies, and where there is an express statement by the parties of their intention to select the law of the contract, it is difficult to see what qualifications are possible, provided the intention expressed is bona fide and legal, and provided there is no reason for avoiding the choice on the ground of public policy.

The rule thus adopted is neither totally subjective nor totally objective, since the parties may choose the "proper law", within certain limits. If the parties do not select such a law, then the court must review the whole facts and circumstances of the contract. Certain older authorities, therefore, are not explicitly overruled, and, it is submitted, the following is an accurate summary of the rules in contract cases:

(i) An express declaration of the "proper law" should be effective provided that:

(a) the choice is in good faith;

(b) the law has a real connection with the contract; and

(c) the choice is not contrary to public policy. ${ }^{221}$

(ii) If the "proper law" is not expressly stated, then an intention as to the "proper law" may be inferred from the terms and nature of the contract and the circumstances surrounding it. ${ }^{222}$

Examples would be arbitration clauses, or submission to a particular law. ${ }^{223}$

(iii) In the absence of an express declaration, or clear inference, the "proper law" may be determined by applying the following presumptions ${ }^{224}$ (the tendency being to give less effect to these presumptions in favour of an objective consideration of all the facts):

(a) the lex loci contractus;

(b) the lex loci solutionis;

(c) the lex situs;

(d) the law of the flag; and

(e) the law of the place of practice.

It is not difficult to see some analogy between the determination of the "proper law" of contract and the "proper law" of a tort. The court must adopt an objective consideration, the degree depending on the type of case, of all the facts and circumstances surrounding the contract or the tort in order to determine with which law the contract or tort has the closest connection. There is the important difference that the parties to a contract are, to an extent, free to choose by which law they wish it to be governed, whereas the parties to a tort

218 [1937] 2 D.L.R. 239.

210 Supra, n. 217.

220 Id. at 289.

221 Per Lord Wright, supra, n. 217.

222 Mackender v. Feldia A.G. [1967] 2 Q.B. 590 at 602.

${ }^{228}$ See e.g., Hamlyn v. Talisker Distillery [1894] Sess. Cas. 21 (21 Rettie, House of Lords).

224 These are based on the previous theories of what was the applicable law, and are now, it is submitted, relegated to the status of presumptions, in the absence of any express or implied choice of the "proper law." 
action will seldom if ever make any previous express choice of which law is to govern the tort.

The constant criticism of the "proper law" of a tort has been that such an approach would introduce grave uncertainty into the law. Yet a similar approach in contract cases is accepted relatively unquestioned. Why should it be any more difficult to determine the "proper law" of a tort than the "proper law" of a contract?

There are further similarities in that certain presumptions can be called in aid for assistance. In torts, the lex loci delicti will often have the most substantial connection, while in contract the lex loci contractus (especially if the contract is made and performed in one country) will usually be the centre of gravity of the contract.

In contracts, the stage was reached earlier than in torts, where the adequacy of rigid mechanical rules was being questioned, and where the application of such rules was not producing the most fair and equitable, or the most rational results. In contracts, a basically objective approach was found most suitable. In torts, this stage has recently been arrived at and the way is open for the adoption of such an objective approach.

In torts, it has been found that the applicable law might vary according to the particular issue which arose as between the parties. Likewise in contracts, the "proper law" approach has helped to solve this very type of problem. Such an approach allows the court to segregate the issue which is at stake in the case. Thus there may well be a difference in the law regulating the formal validity and the essential validity of the contract. ${ }^{225}$

Not only does this approach allow the court to segregate the issues, but it permits the development of specific rules for particular contracts. It is foreseeable that a different rule might be applied to contracts of agency, maritime and aviation contracts, and contracts in respect of immovable property.

The most significant factor deducible from this analogy is that the basis of the criticism of the "proper law" of a tort may be unfounded. The type of approach which the "proper law" demands does not place too onerous a burden upon the judiciary. Such an onus has been met and faced by the judges in contract cases, and, it is submitted, it can be faced successfully in tort cases.

\section{Recognition of foreign divorce decrees}

The development of an objective approach to the whole facts and circumstances of each case has not been limited to the field of contracts, and some cogency has been added to the argument for a "proper law" approach by recent developments in the area of recognition of foreign divorces.

The traditional common law approach to questions of status in the conflict of laws was that such questions should be regulated exclusively by the law of the domicile. 226 To this basic rule certain appendages had been added, which served to dissipate somewhat the injustices of such a hard rule, and of these there are at least two. In the case of Armitage v. Attorney-General ${ }^{227}$ the court developed a new rule of indirect recognition to the effect that an English court would recognise as valid a decree granted by a court other than the court of the

225 It is sufficient that a contract be formally valid according to the lex loci contractus: Guepratte v. Young (1851) 4 De G. \& Sm. 217. Matters of substantial validity, however, are within the jurisdiction of the "proper law", which may not be the locus contractus.

220 Le Mesurier v. Le Mesurier [1895] A.C. 517.

227 [1906] P. 135. See also, Re Jones (1960) 25 D.L.R. (2d) 595 (B.C.S.C.) 
domicile provided that that decree was recognised by the court of the domicile. ${ }^{228}$ At a much later date the case of Travers v. Holley ${ }^{229}$ gave rise to a further relaxation of the original rule. In that case, the court, in refusing a decree, would have been refusing recognition to a divorce where jurisdiction was assumed on grounds almost identical to those which existed in England. The rule developed, therefore, was that an English court would recognise a decree granted in another jurisdiction, if granted on the basis of circumstances similar to English statutory jurisdiction.

It was not until 1967, however, that the citadel of domicile finally came tumbling down in the case of Indyka v. Indyka, ${ }^{230}$ the facts of which were as follows:

A wife, who had always resided in Czechoslovakia but whose Czech-born husband had acquired a domicile of choice in England after the 1939-45 war, was granted a decree of divorce by a Czechoslovakian court which became final in February, 1949. In 1959, the husband married his second wife in England, and in 1964 she petitioned for divorce on grounds of cruelty. The case turned upon the date of the Czech decree, which was, in fact granted prior to the enactment of the Law Reform (Miscellaneous Provisions) Act in England.231 In the Court of Appeal ${ }^{232}$ the consensus of opinion (Lord Russell dissenting) appeared to be that the date of the decree did not matter, and that the doctrine of Travers v. Holley ${ }^{233}$ should be considered retroactive in operation. In the House of Lords, ${ }^{234}$ however, the decision, though the same in result, was based upon different grounds. Lord Reid revived the concept of the matrimonial home and the community with which the spouses are most closely connected. ${ }^{235}$ Lord Morris of Borth-y-Guest adopted a similar view stating the "the first wife at the time when she presented her petition in Czechoslovakia undoubtedly had a real and substantial connection with that country."2se Lord Pearce stated the concept of matrimonial home quite clearly: ${ }^{237}$

Undoubtedly the country of the nationality was the predominant country with regard to the parties to this marriage, and as such its decree ought to be recognised in this country.

Lord Wilberforce accepted this proposition and proceeded to comment upon the operation of such a broad basis of recognition: ${ }^{288}$

How far should this relaxation go? In my opinion, it would be in accordance with the developments I have mentioned and with the trend of legislation - mainly our own but also that of other countries with similar social systems - to recognise divorces given to wives by the courts of their residence wherever a real and substantial connection is shown between the petitioner and the country, or territory, exercising jurisdiction. I use these expressions so as to enable the courts .... to consider both the length and quality of the residence and to take into account such other factors as nationality which may reinforce the connection. Equally they would enable the courts .... to reject residence of passage or residence .... resorted to by persons who properly should seek relief here for the purpose of obtaining relief which our courts would not give.

Lord Pearson ${ }^{239}$ gave reasons why a new basis was needed for the recognition

228 This rule also applies to decrees of nullity. See Abate v. Abate [1961] P. 29.

229 [1953] P. 246. Followed in Re Allarie (1964) 41 D.L.R. (2d) 553 (Alta. S.C.).

230 [1969] 1 A.C. 33.

231 These provisions are now contained in the Matrimonial Causes Act 1965, c. 72 .

232 [1966] 3 W.L.R. 603.

238 Supra, n. 229.

284 Supra, n. 230.

235 Id. at 67.

$238 \mathrm{Id}$. at 77.

287 Id. at 91.

238 Id. at 105.

${ }^{230}$ Id. at 108. 
of foreign divorces. He referred to the increased mobility and extensive displacements of persons, increased international trade and travel, and the increasing frequency of divorces.

In view of these changes Lord Pearson was prepared to adopt a more general approach based upon a real and substantial connection between the petitioner and the jurisdiction issuing the decree.

In the face of judicial and legislative relaxation the rule in Le Mesurier ${ }^{240}$ was finally displaced by a more general one. On the facts of Indyka it was not difficult to see why the Czech decree should have been recognised - the wife was deserted in the country of the matrimonial home and she remained there, later acquiring a decree of divorce from the Czech court. It is significant, however, to consider the way in which the Indyka rule has been treated in later cases on the subject.

The rule was applied next in the case of Angelo v. Angelo ${ }^{241}$ where a German au pair girl married an Englishman in England, from where they moved to France. She eventually left him and returned to Germany, where she obtained a decree within six months of her return. Germany was her place of birth, nationality and habitual residence, and the English court, therefore, was prepared to concede that a real and substantial connection existed. The rule was also applied in Blair v. Blair \& Barlie ${ }^{242}$ in which Cumming-Bruce J., in the course of his opinion, stated that "... it is now open to an English court of first instance to consider all the facts appertaining to the grant of a decree by foreign court, whether to husband or to wife, and to determine whether, in spite of the fact that there was no domicile of [the petitioner], . . . the decree should be recognised." ${ }^{243}$ This rule has been applied in the later cases of Peters v. Peters, ${ }^{244}$ Mayfield v. Mayfield, ${ }^{245}$ Brown v. Brown, ${ }^{246}$ and Tijanic v. Tijanic, ${ }^{247}$ in all of which the words "real and substantial connection" were used freely.

The rule was given its widest application in Mather v. Mahoney ${ }^{248}$ where it was held that recognition would be given to a decree given by a court whose decree would have been recognised by a court which had a real and substantial connection with the petitioner. (In fact, an application of the rule in Armitage ${ }^{249}$ with "real and substantial connection" replacing "domicile").

Recent Canadian divorce legislation ${ }^{250}$ makes it unclear whether the English decisions are still applicable in Canada, since the Divorce Act has its own built-in conflicts rules. However, these cases are cited not so much for their content, as for the methods and approach adopted by the judiciary. It is significant that for the reasons given (which bear a marked similarity to the statements made in tort cases) the courts have found it necessary to find a new basis for the rules and this they have found in a broad rule based on "real and substantial connection". In other words, the court is now prepared to look at all the facts and circumstances of the case in order to determine whether or not a foreign divorce

240 Supra, n. 226.

241 [1967] 3 All E.R. 314.

242 [1969] 1 W.L.R. 221 (Birmingham Assizes).

248 Id. at 224.

244 [1968] P. 275.

245 [1969] P. 119.

246 [1968] P. 518.

247 [1968] P. 181.

248 [1968] 3 All E.R. 223. Cf. Mountbattan [1959] P. 43 where an attempt to add an extra link to the Armitage rule was not permitted.

219 Supra, n. 227.

250 R.S.C. 1970 , c. D-8. 
should be recognised. One might almost say that the courts are approaching a "proper law of divorce recognition".

\section{A PROPER LAW APPROACH - THE AMERICAN EXPERIENCE}

When the case of Boys v. Chaplin ${ }^{251}$ was heard by the House of Lords, the bench was disposed to comment on the "proper law" approach which has been used in many states of the United States, and which has been embodied in the Restatement Second. ${ }^{252}$ Lord Hodson ${ }^{253}$ was of the opinion that the new approach would be productive of uncertainty. Lord Wilberforce was even willing to sacrifice the system which has contributed so significantly to the development of substantive tort law by saying that "case to case decisions do not add up to a system of justice". ${ }^{254}$ What is most surprising in these comments is that neither judgment contains anything more than a cursory examination of the American experience, which began six years before Boys v. Chaplin was heard.

It would seem in order, therefore, to examine the "proper law" approach in the United States, in order to determine, at least, whether such criticism is valid, and if that is the case, whether defects so discovered might be avoided if the approach were adopted in another jurisdiction.

The use of a "proper law" approach was heralded by the decision in Babcock v. Jackson, ${ }^{25 s}$ marking a significant departure from the former strict adherence to application of the lex loci delicti. In that case, three New York residents embarked upon a weekend trip to Canada. They left from New York, where their car was registered and insured, and planned to return there. In the course of the journey, a passenger in the car was injured by the negligent driving of the defendant. The accident occurred in Ontario, where a passenger (guest) cannot recover from a driver (host) except where the driver has displayed gross negligence. Mr. Jackson, the driver, was sued for damages in New York, where no such limitation on a guest-host suit exists. The locus delicti was indeed fortuitous, and this was quickly pointed out by the court. If however, the established rule of applying the lex loci delicti was not appropriate in the instant case, then some other basis had to be found. The other basis was found by "giving controlling effect to the law of the jurisdiction which, because of its relationship or contact with the occurrence or the parties, has the greatest concern with the specific issue raised in the litigation". ${ }^{250}$

This decision obviously marked a departure from the previous rule in that it meant that the lex loci delicti was not invariably to be applied. It is significant, however, that the decision went further since the choice of law determination was to be made not with respect to the general tort alleged, but in the light of the specific issue raised in the litigation. This was an important factor since the specific issue in the case was not the fact of negligence, nor the possibility of a collusive suit against an insurer, but whether the parties, because of their relationship, could bring a suit inter se. That being the case, it is not surprising that New York law should be applied to a dispute between two New York residents, whose relationship was formed there and was to end there, and, presumably, whose reasonable expectation would be that their relationship would be governed by that law. Fuld J. ${ }^{257}$ opined that such an analysis would be in the interests of justice and fairness, and he implicitly placed those interests

251 [1969] 3 W.L.R. 322.

252 American Law Institute, supra, n. 5.

253 Supra, n. 251 at 330.

254 Id. at 343.

255 Supra, n. 49.

256 Id. at 283 per Fuld J.

267 Id. 
above the advantages of certainty, predictibility, and ease of application, which had been claimed for the older rule.

Admittedly, there can be little criticism of the justice of the result in Babcock, given the factual setting of the case and minimal contact with the locus delicti. The test of the new approach, therefore, would be in its application to less startling factual settings, and it was not long before the New York Court of Appeals had the opportunity for further development of the "proper law" approach in the case of Dym v. Gordon. ${ }^{258}$

The action in Dym arose out of a motor vehicle accident which gave rise to a guest-host suit. Both the parties were New York domiciliaries but the accident and negligent conduct took place in Colorado, which had enacted a standard "guest statute". The trial court had held that New York law was applicable, using the Babcock principle to say that a "guest statute" contravened the policy of New York law. That decision was reversed by the Appellate Division. The agreed set of facts presented to the Court of Appeals was that both parties, New York domiciliaries, were temporarily resident in Boulder, Colorado, having travelled there separately, by different means of transportation to attend summer school. Before leaving New York, there was no arrangement to meet in Colorado, or that the plaintiff would, at any time, ride in the defendant's car. The accident occurred during a short trip within Colorado, there being no plans for any other trip. The contacts with New York, presented by the plaintiff, were the domicile of the parties and the registration and insurance of the car. The court, having isolated the issue as an automobile guest-host relationship, looked to the seat of the relationship as the applicable law, and supported this decision by reference to similar decisions in respect of husband and wife actions, ${ }^{259}$ and workmen's compensation cases. ${ }^{200}$ The argument that the application of Colorado law would contravene the policy of New York was summarily dismissed, on the basis that public policy per se plays no part in a choice of law problem, and, further, should not be invoked unless some fundamental principle of justice is violated. On the other hand, the court examined the policy embodied in the relevant Colorado law, and was persuaded that Colorado had a significant interest in seeing that the assets of a negligent defendant should not be dissipated, thereby diminishing the right of recovery of the persons in the car of the blameless driver.

A very strong dissenting opinion was voiced by Fuld J., who criticized the majority for substituting a new mechanical rule for the old locus delicti rule. He stressed that the choosing of the "seat of the relationship" might not always be appropriate and proceeded to explain why it was not in the instant case. He argued that the issue before the court was whether the injured party should recover from the negligent actor. He pointed out that the action was brought in New York against a New York driver and his insurance company. The policy of the Colorado "guest statute", which he explained primarily as an attempt to protect Colorado insurers from collusive suits, could have no relevance to the instant case. ${ }^{261}$

At first blush, a degree of criticism may be directed at the uncertainty created by the diversity of opinions in the court which originally handed down the Babcock decision. The uncertainty is not necessarily the result of employing the Babcock principle, since it is described as a method of analysis and not a solution per se, but perhaps has more to do with the integration in the principle

258 (1965) 262 N.Y.S. (2d) 463 (Court of Appeals of New York).

250 Mertz v. Mertz (1936) 3 N.E. (2d) 597 (Court of Appeals of New York).

200 Alaska Packers Ass'n. v. Industrial Ace. Comm. of California (1935) 249 U.S. 532.

261 Supra, n. 258 at 472. 
of the requirement that the court examine the policy of the possibly applicable laws. It has already been pointed out in this work, ${ }^{202}$ that the identification of the particular policy reason for the enactment of a statute is no easy task. In fact, the present writer would doubt that this can ever be done satisfactorily. The courts of Canada and England have not, to date, seen the necessity for distinguishing between true conflicts and false conflicts, the latter expression denoting a situation where two laws may be applicable, but each law embraces the same policy. In the United States, on the other hand, this distinction, and its inherent policy examination, seems to have been an accepted part of conflicts doctrine for some years. Canadian and English decisions would support the proposition that a conflict of laws exists wherever there is a choice between two applicable laws. Indeed, the very basis of conflicts rules is the producing of a rational set of rules to deal uniformly with any case in which a foreign element intrudes. In such a case a choice of law exists regardless of the policies embodied in the relevant statutes and cases. Public policy may and will be relevant when the choice of law has been made and the question of applying the foreign law is before the court, but it surely cannot be relevant in making a choice of law decision.

The requirement that the policy be examined as part of the choice of law process has become a rather sophisticated one, and some jurisdictions in the United States have stated the policy considerations to be considered in solving a choice of law problem. It is apparent that the "policy" in issue here is not really the concept of "public policy" which has always been a part of conflict of laws. "Public policy" in the latter sense was defined by Cardozo J. in a celebrated case, ${ }^{263}$ where he said:

The courts are not free to refuse or to enforce a foreign right at the pleasure of the judges, to suit the individual notion of expediency or fairness. They do not close their doors unless help would violate some fundamental principle of justice, some prevalent conception of good morals, some deeprooted tradition of the common weal.

Presumably this concept of "public policy" is still applicable as a separate consideration from the policy-oriented approach to choice of law.

A clear illustration of the use of a "policy" choice-influencing consideration is the case of Pfau v. Trent Aluminum Company. ${ }^{204}$ The plaintiff, a Connecticut domiciliary, was injured in lowa while a passenger in an automobile driven by a New Jersey domiciliary, owned by a New Jersey corporation, and insured in New Jersey. Both plaintiff and defendant were temporarily resident in Iowa while attending school, and the journey during which the accident occurred was a weekend trip to Columbia, Missouri. The relationship of guest and host was to begin and end in Iowa. It was submitted that the law of Iowa, being the seat of the relationship and the locus delicti, should apply. In order to deal with that submission, the court proceeded to examine the purposes of Iowa's guest-statute, as articulated by Iowa courts. Those purposes were found to be: to cut down litigation arising from the commendable unselfish practice of sharing with others transportation in one's vehicle, to protect the Good Samaritan from claims based on negligence by those invited to ride as a courtesy; to prevent ingratitude by guests; to prevent suits by hitch hikers; and to prevent collusive suits by friends and relatives resulting in excessively high insurance rates. Since the insurance in question was placed in New Jersey, there could be no collusion against an Iowa insurer; no Good Samaritan Iowa host needed protection; and there was no inhospitable Iowa guest. The court concluded, therefore, that, as a matter of policy, the Iowa statute had no application to the present case.

262 See II. Choice of Law Policy.

208 Loucks v. Standard Oil Co. of New York, supra, n. 178 at 111.

28ะ (1970) 263 A. (2d) 129 (Supreme Court of New Jersey). 
Non-application of the Iowa guest-statute would not transgress any of the purposes enunciated by the Iowa courts. The question then before the court was whether to apply Connecticut or New Jersey law. Connecticut was the domicile of the plaintiff, whereas New Jersey was the domicile of the defendant, the place of insurance coverage, and car registration, and the forum. It was found that each state had the same policy of applying ordinary negligence principles to guest-host relationships. In the court's opinion, therefore, there was a false conflict, and the law of Connecticut, being a state having a significant interest (one which was not identified by the court) was chosen. ${ }^{285}$ No reasons were given for the choice of Connecticut law, and on the basis of the contacts listed above, New Jersey would have the closest connection with the case, qualitatively and quantitatively.

The proponents of a "proper law" approach have stressed that the points of contact must be weighed quantitatively as well as qualitatively. This assertion follows logically from the requirement that the court look to the points of contact with the specific issue in litigation. Depending on the specific issue, a particular point of contact may carry more or less weight. The distinction between a rule of conduct and the incidents of a status or relationship has already been drawn in the context of the propriety of a "proper law" approach to the multifarious kinds of tort action which may arise. That distinction also serves to illustrate the necessity of assessing qualitatively the points of contact with any given case. The locus delicti will always be a point of contact, but will normally carry more weight in relation to a rule of conduct issue than an issue arising out of a relationship such as husband and wife, or employer and employee. That point was stressed in the Wisconsin case of Heath v. Zellmer, ${ }^{268}$ where Heffernan J. said: ${ }^{267}$

Nor does it mean that foreign law will be applied even though the contacts with a foreign jurisdiction are quantitatively overwhelming, for, if the foreign jurisdiction's contacts are less relevant qualitatively ... the effectuation of Wisconsin policy may be the most decisive element . . . .

In the same judgment, it was conceded that some uncertainty must inevitably result from the new approach. However, it was suggested that courts could approach cases in a consistent manner, so that decisions not only would have precedential value for their own decision making, but also serve as a guide to Bench and Bar. That in turn necessitates a basis of expressed reasons and consistently employed standards.

It is unfortunate that such a lucid explanation of principle was lost in the decision of the actual case, since the decision portrays a distinct "forum-bias" and an almost arrogant treatment of the law of another state. ${ }^{288}$

The present writer would submit that the extent of any uncertainty generated by a qualitative assessment is tolerable in view of the more rational nature of a "proper law" approach. This approach, like any other new legislation or decision, can only be solidified by the subsequent development of a body of case law.

In some jurisdictions a list of choice-influencing considerations has been enunciated by the courts. The five considerations suggested by Robert Leflar ${ }^{269}$

265 The court also neatly side-stepped the submission that the reference to Connecticut law should include a reference to its choice of law rule (the lex loci delicti) thus raising the question of the transmission of a renvoi. See supra, n. 264 at 136-137.

286 (1967) 151 N.W. (2d) 664 (Supreme Court of Wisconsin). For a fuller discussion of Heath v. Zellmer, see infra.

267 Id. at 670.

268 At 674, the Indiana guest-statute was described shortly as "an anachronism".

260 Leflar, Choice-influencing Considerations in Conflicts Law, 41 New York University L. Rev. 267. 
were adopted in Wisconsin in 1967, in the case of Heath v. Zellmer. ${ }^{290}$ These considerations were as follows:

(i) Predictability of results.

(ii) Maintenance of interstate and international order.

(iii) Simplification of the judicial task.

(iv) Advancement of the forum's governmental interests.

(v) Application of the better rules of law.

In that case, the defendant, for some months prior to the accident, had been using her father's car for business and pleasure. The defendant was a resident of Ohio, but her parents lived in Indiana where the car was registered and insured. The defendant, while visiting Indiana, went with her mother and sister to visit relatives in Wisconsin. During the return from Wisconsin, with three Wisconsin relatives as passengers, their automobile collided with a car driven by Zellmer, a Wisconsin resident. The passengers in the first car sued Zellmer, who interpleaded the driver of the first car as defendant also. Indiana law had a guest-statute, requiring "wanton or wilful conduct" as a condition of liability whereas Wisconsin did not. Indiana, according to the court, had the following contacts: the trip began and was to end there; the relationship between the mother, sister and host began there and was to continue until their return; the automobile was owned by an Indiana resident, and was registered and insured there. Wisconsin had the following contacts: it was the locus delicti; $;$ Zellmer, the other driver, was a Wisconsin resident; there were three additional Wisconsin passengers in the car; Meyer, the first driver, had become a Wisconsin resident after the accident, but before the commencement of suit. The court proceeded to examine Leflar's five considerations in respect of the instant case:

(i) Predictability of results ranked low in the estimation of the court, since it was stated that that factor had no relevance to a tort that was not intended or planned. It was suggested that this factor was of special significance in consensual arrangements only, where it is imperative that the parties know their rights in advance.

Despite the low ranking of this factor, it is submitted that this does not and should not rule out some resort to the reasonable expectations of the parties, as embodied in the foresight of a reasonable man.

(ii) Maintenance of interstate and international order. This factor was explained in a negative sense, that a state with a minimal interest only should not seek to impose upon another state's free flow of commerce or exercise of legitimate policies. It was stressed that this factor should not be employed to disguise a forum-bias.

It is submitted that this factor should not be a significant one in Canada. It is a product of the complex policy-oriented approach to inter-state and constitutional matters in the United States, which, fortunately, has not been a part of inter-provincial and federal-provincial relations in Canada. Moreover, despite the warning against forum-bias, this factor is prone to use for that purpose. ${ }^{272}$

270 Supra, n. 266.

271 Id. at 669 . Having stated that the old locus delicti rule had been abandoned, the court nevertheless said that this contact was significant since it would have been the deciding factor under the old rule.

272 See e.g., Conklin v. Hornes (1968) 157 N.W. (2d) 579, where Heffernan J., in the Supreme Court of Wisconsin, appears to have fallen prey to the very evils he is waming against in Heath v. Zellmer, supra, n. 266. 
(iii) Simplification of the judicial task. Heffernan J. admits that, though he would prefer an easily applied rule of law, this cannot be at the expense of justice. He goes on to remark that the judicial task is rarely simplified by the application of a foreign law.

The difficulties implicit in dealing with foreign law should not form an excuse for the application of the lex fori. Our courts have made provision for the proving of foreign law by way of expert testimony, which must satisfy the court as a matter of fact as to the nature and extent of that law. Moreover, there is provision for the non-application of a foreign law if it involves a procedure which is unknown to the forum or a remedy which is inappropriate to the enforcement of the foreign right. ${ }^{273}$

(iv) He further expresses a presumption that the applicable law should be that of the forum, to be displaced by a justice-seeking foreign law with more significant contacts. The example he cites is an anachronistic court-made law of the forum which could be avoided by the choice of a foreign law. Since courts are instruments of the state, he argues, it is the duty of the court to identify and effectuate that state's policies. This includes weighing the respective standards of justice and fairness embodied in the lex fori and foreign law.

It is submitted that the duty of the court is to administer justice and that the division of powers should mean that the judiciary is independent, and thus not influenced by the state or required to act as an instrument thereof. The duty of the court is at an end when it has applied the known and existing law in a fair and consistent manner. If that does not effectuate the policies of the province or dominion then the law can be altered by the Legislature or Parliament.

(v) Application of the better rule of law. This appears to be an accepted aspect of choice-influencing considerations. If a law is obsolete and useless, then it is to be avoided. Heffernan J. emphasises, in defence of the factor, that this is an objective choice of preferred law and not of preferred parties. In the opinion of the author, this is a rather fine line of distinction at any time.

Perhaps this factor stems from the more radical approach of American judges to the possibility of judge-made law. Although English and Canadian law has profited from the judicial development of principle, and this possibility is a proud boast of the common law system, the approach has been much more cautious than in the United States. Moreover, England and Canada already have a tried and tested concept, namely "public policy" which is designed to protect the forum from a repugnant foreign law. It would appear that the American "better law" approach is a much broader concept than the existing "public policy" safeguard. For instance, in the present case, the "better law" choice was between a "guest-statute" on the one hand, and the ordinary rules of negligence on the other. The "gueststatute" may have been an anachronism in Wisconsin, but certainly not in other states, nor in many external jurisdictions including many provinces in Canada. Although the policy of Wisconsin was to compensate the injured party, it cannot be said that the application of a foreign "gueststatute" was repugnant to the public policy or morality of Wisconsin. In a converse situation, where the foreign law was deemed better than the lex fori, it would be circumventing the judge's duty to apply the law of the jurisdiction in which he is sitting, merely because he thinks a foreign law is

273 For a right which was recognised, but could not be enforced in the forum, see Phrantzes v. Argenti [1960] 2 Q.B. 19, especially per Lord Parker C.J. at 35. 
better. It is the duty of the legislative body to change the law, if it is not satisfactory.

It is submitted that the points of contact relevant to a "proper law" approach to choice of law must be weighed quantitatively and qualitatively. That, however, does not mean that the choice-influencing considerations discussed above should be part of that assessment. In the present writer's opinion, only the first factor of predictability would be appropriate for Canadian courts, and that could be invoked by reference to the reasonable expectations of the parties. Canadian courts are neither accustomed to nor would they benefit from employing the policy-oriented approach of United States courts. "American Realism" cannot be the basis for acceptance of a "proper law" approach.

It is submitted that the "proper law" approach is a more rational solution since it removes the elements of rigidity and inflexibility which are present in the traditional Phillips v. Eyre rules. In the latter rules, all issues are governed by the lex fori, once it is established that the activity complained of is "not justifiable" by the lex loci delicti. In this approach, it makes no difference whether the forum has any connection, either substantial or insubstantial, with the act complained of, provided the defendant is amenable to the jurisdiction of the courts of the forum. The only other point of contact canvassed by these rules is the locus delicti, and then, only in the context that the act be "not justifiable" there. ${ }^{274}$

It is inherent in the "proper law" approach that the precise issue before the court be characterized and a choice of law be made in respect of that issue. Since the issues which may arise in a tort action are numerous and varied, it is reasonable that the choice of law rules should be related to the nature of the issue which arises, rather than a blanket choice of laws of the forum as is the case with the first part of the rule in Phillips v. Eyre. Moreover, the varied nature of tort issues is provided for in a "proper law" approach by allowing resort to points of contact, in appropriate circumstances, other than the lex fori and the locus delicti. Thus the Restatement of Conflict of Laws (Second) ${ }^{275}$ states the general principle as follows:

S. 145. The General Principle

(1) The rights and liabilities of the parties with respect to an issue in tort are determined by the local law of the state which, with respect to that issue, has the most significant relationship to the occurrence and the parties ....

(2) Contacts to be taken into account in applying the principles of S. 6 to determine the law applicable to an issue include:

(a) the place where the injury occurred,

(b) the place where the conduct causing the injury occurred,

(c) the domicile, residence, nationality, place of incorporation and place of business of the parties, and

(d) the place where the relationship, if any, between the parties is centered.

These contacts are to be evaluated according to their relative importance with respect to the particular issue.

The sections which follow the general principle fall under the heading of particular topics, and give sub-rules for the application of the general principle to a particular tort such as misrepresentation (S. 148), personal injuries (S. 146), multi-state defamation (S. 150), rights of privacy (S. 153). The sub-rules, then go on to state the issues which are to be governed by the laws so chosen, including the tortious character of the conduct (S. 156), standard of care (S. 157),

274 "Not justifiable", the Machado v. Fontes appendage is still applicable in Canada, on the authority of Gronlund v. Hansen, supra, n. 80.

275 American Law Institute, 1971. 
defences (S. 161), contributory fault (S. 164), measure of damages (S. 171), and vicarious liability (S. 174).

Each of the sub-rules for choice of law is couched in terms of a presumption only, and makes provision for the displacement of the law presumed to apply by a law which has a more significant connection with the issue and the parties. In each case, a Reporter's Note is appended to the sub-rule referring to the body of case-law which has been established and which illustrates the normal application of the law presumed to apply. Much of the uncertainty that would otherwise flow from a general principle requiring the application of the law having the "most significant connection" is dissipated by the presumptive sub-rules indicating the manner in which the general principle should be applied. Insofar as these sub-rules have commanded general recognition the "proper law" approach may also claim a fair degree of consistency.

It is in order, therefore, to examine some of the issues in which a "proper law" approach has been applied. Reference has already been made to the "relationship" issue which may arise in torts - can a wife sue her husband, or a guest his host, or an employee his fellow-servant or employer? It would seem fairly well-settled in the United States that this question should be determined by reference to where and how the relationship was formed. One would look, therefore, as a general starting point, to the domicile of husband and wife, the place where a guest-host relationship was formed and was to end, and to the place of employment. Thus in Clark v. Clark ${ }^{276}$ this question was resolved by reference to the law of New Hampshire, the domicile and forum, and not the law of Vermont, the locus delicti. In Fuller v. Greenup ${ }^{277}$ the California court applied the law of Alaska to a guest-host case arising out of an accident in British Columbia. In the opinion of the court, the agreement by two Alaska domiciliaries to travel together and share the expenses of a trip to Califormia and back, was made in contemplation that their rights would remain fixed under the substantive law of their domicile, and the place where the agreement was entered into. In Hablas v. Armour \& Company, ${ }^{278}$ a case concerning wrongful dismissal of an employee, the court looked to the seat of the employment relationship and the place where the loss was suffered, rather than to the place where the alleged misrepresentation, which formed the basis for the assertion of wrongful dismissal, was made.

These issues may be contrasted with cases involving a determination of whether tortious conduct has actually occurred. For instance, failure to ensure maintenance of machinery, failure to use due care, and failure to give proper notice of dangerous products, are all questions which should be determined by the law of the place where the alleged negligent failure occurred. This was the approach adopted by the Privy Council in the case of Distillers Co. (Bio-Chemicals) Ltd. v. Thompson, 279 where a drug manufactured in England was ultimately consumed in New South Wales, causing harm to the plaintiff there. In giving judgment for the court Lord Pearson stated ${ }^{280}$ that negligence of the defendant consisted, not in the negligent manufacture of the drug in question, but rather in the failure to give a warning that the drug might prove dangerous if taken by an expectant mother in the first three months of pregnancy. He went on to state ${ }^{281}$ that the warning could have been given either in England

278 Supra, n. 58. See also, Doiron v. Doiron (1968) 241 A. (2d) 372 (Supreme Court of New Hampshire).

277 (1968) 72 Cal. Rptr. 531 (Court of Appeals).

278 (1959) 270 F. (2d) 71 (United States Court of Appeals).

270 [1971] 2 W.L.R. 441.

280 Id. at 449.

281 Id. 
at the time of manufacture, or in New South Wales at the time of distribution. As a result, he concluded, the plaintiff was entitled to complain of the lack of such communication in New South Wales as negligence by the defendant in New South Wales, causing loss to the plaintiff there. In Orr v. Sasseman, ${ }^{282}$ an action seeking damages for alienation of affection, the major issue was whether the conduct complained of did constitute alienation of affection. The issue was determined, therefore, by the law of Georgia, the place where the alleged alienation had occurred, and not by the law of Illinois, the domicile of the parties. A similar analysis should have been applied, but was not, in the case of Decker v. Fox River Tractor Co. ${ }^{283}$ There the plaintiff, resident in Pennsylvania and owner of a farm there, was injured there when he came into contact with the moving parts of a farm machine. The machine was manufactured in Wisconsin, sold to a Pennsylvania implement dealer, and ultimately resold to the plaintiff. The law of Pennsylvania provided that a finding of contributory negligence on the part of the plaintiff was a complete bar to any action, whereas the law of Wisconsin did not. The court chose the law of Wisconsin, on the basis that the state's law with respect to contributory negligence was the "better law". In fact, it was expressly stated, though without reasons, that it was not appropriate to make a choice of law determination simply by counting the number of contacts. $^{234}$ If that statement was intended to reject a purely quantitative assessment of the points of contact, then it might be justified, but the tenor of the judgment would indicate the absence of any assessment, either quantitative or qualitative of the points of contact in the case. Further, it would appear that the only choice of which the court took cognizance was the choice of the "better law" as between the comparative negligence approach taken in Wisconsin and the complete bar of contributory negligence in Pennsylvania. It is submitted that there were two issues: (i) what law should govern the question of negligence on the part of the manufacturer, and (ii) what law should govern a plea of contributory negligence. On the facts before the court, it is submitted that the first issue should have been governed by the place where the defective product was sold to the ultimate consumer, and where the eventual loss was suffered, thus bringing the tort into being (Pennsylvania). The second issue should have been decided by the law of the place where the conduct occurred, being the permanent home of the actor, the place where the ownership of the machine was acquired and where maintenance and service would be obtained, and being in accord with the reasonable expectation of the party involved ${ }^{285}$ (also Pennsylvania). The mere fact that the machinery in question was originally manufactured in Wisconsin should not, it is submitted, have been conclusive of the application of that state's law.

The multi-jurisdiction tort, where duty, breach and loss occur in different jurisdictions does create some difficulty. It is precisely in this type of case, however, that a "proper law" approach is most valuable. A defamatory statement may be issued in one place and read or received in many other places. The plaintiff may suffer loss in all those places. Normally the law of the plaintiff's domicile would be chosen on the basis that the domicile is also the place of principal reputation, but, that indication is not a conclusive one. In the cases of Palmisana v. News Syndicate Co. ${ }^{286}$ and Negri v. Schering Corporation ${ }^{287}$ the courts held that the law of the place of publication of the defamatory matter

282 (1956) 239 F. (2d) 182 (United States Court of Appeals).

289 (1971) 324 Fed. Supp. 1089 (United States District Court, Wisconsin).

284 Id. at 1090.

285 It is submitted that this case is an excellent illustration of a policy analysis clouding an objective view of the points of contact.

280 (1955) 130 Fed. Supp. 17.

287 (1971) 33 Fed. Supp. 101 (United States District Court, New York). 
should prevail, since, in each case, the law appeared to have the most significant relationship to the tort. In the first case an action alleging libel was brought against the defendant newspaper, a citizen of New York, having its principal office there. The plaintiff, a citizen of New Jersey, alleged that an editorial in the said newspaper was capable of the innuendo that the plaintiff was suspected of criminal activities. In an action of this nature, the court was of the opinion that the state having the most significant connection with the issue was the place where the plaintiff had his principal reputation. Although that would normally be the plaintiff's domicile, the court was not prepared to transform that normal occurrence into a rigid rule. ${ }^{288}$ In the second case, a movie actress brought action against an advertiser under a New York statute which created a cause of action in a person whose name or picture is used for advertising purposes without the person's consent. The advertisement in question, was a double-page spread including a nine-inch high picture of the plaintiff as she appeared in her first silent movie. The plaintiff was resident and domiciled in Texas, and the advertisement was widely circulated in New York and elsewhere. The defendant argued that liability should be governed by the law of Texas, being the principal home of the plaintiff, and where there was no remedy. The court, however, refused to accept that contention, preferring to base its choice of law of New York on the ground that the offending publication had been widely circulated in New York, where the plaintiff had suffered damage, and the plaintiff was entitled to sue in New York, for the violation of the New York Civil Rights statute which the defendant had committed. Although this result was consistent with previous New York decisions which interpreted the Civil Rights statute, it is not unimportant to point out that the law of Texas would have given the plaintiff no remedy. Such a consideration is preferable to an inflexible resort to the lex loci delicti and the lex fori, which is ill-suited to provide for the multijurisdictional tort. Despite the possibility of some uncertainty, the "proper law" approach at least deals in a rational manner with such torts.

The advent of insurance schemes to replace a tort liability has been widely advocated, and is accepted to its greatest degree in employment situations. This should not detract from the use of a "proper law" approach since that is merely a method to be employed in selecting the applicable law. Once the applicable law is chosen, then the law must be examined to determine the incidents of the compensation scheme. As it is stated in the Restatement (Second):

Hence the principal problem in the area is not one of choice of law but rather what range of application to persons and things without the state will be given by a state to its own workmen's compensation statute.

Thus in Elston v. Industrial Lift Truck Co. ${ }^{289}$ the court was required to decide what law to apply to a dispute arising out of injury to an employee in New Jersey, in conjunction with the use of equipment manufactured in Pennsylvania. The employee, in accordance with New Jersey law, received compensation, and, in addition commenced suit against the manufacturer for negligent inspection of the machinery prior to delivery. By Pennsylvania law, the alleged tort-feasor was entitled to join the employer as a joint tort-feasor, but by New Jersey law, he was not. The sole issue, therefore, was one of choice of law. In those circumstances the court held that the law most closely related to the issue was that of New Jersey and it was applied accordingly. Similarly, if the issue were whether an employee could sue in tort as well as recover compensation, this would resolve itself into a question of identifying the place in which a claim for compensation was or could be made, and then determining, by the law of the place, what were the consequences of receiving compensation. This would be

288 Id. at 106.

289 (1966) 216 A. (2d) 318 (Supreme Court of Pennsylvania). 
more akin to the subject of "judgments" than anything else. If the compensation scheme stated that a claim was in lieu of all rights arising out of the accident, then there could be no such action. If it was otherwise, then an employee could proceed by way of an action in tort to recover damages. A plea of res judicata would be successful in a second action only if the first settlement represented a full and final adjudication of the rights of the parties. ${ }^{200}$ The possibility of more than one claim being made can be dealt with by requiring the prior claim to be brought in as a set-off against a later award. As to the question of which compensation scheme should determine common law liability for tort, it would seem that this should be precluded if it is not permitted by any of the jurisdictions in which a claim could be made, provided that jurisdiction had some connection with the injury or the parties. If this were not the case, the employer would be required both to pay insurance premiums and to be prepared to pay damages in respect of his common law liability. The incidents involved in the choice of law which includes a compensation scheme may be more complex than problems such as limitation of actions or the existence of a specific tort such as invasion of privacy, but the approach in each case is the same - which law has the most significant relationship to the issue in dispute.

The approach adopted by the Restatement recognises the difficulties involved in the application of workmen's compensation statutes. That approach starts from the premise that such a statute usually has two basic purposes: (i) to benefit the employee by providing that regardless of fault he will be compensated for all injuries received in the course of his employment, and (ii) to place some restrictions upon the cost of industrial accidents by providing that the employer shall be liable for an employee's injuries only in accordance with a fixed scale of damages, and shall be relieved from liability for tort or wrongful death. Given these purposes, a state may constitutionally award compensation if the injury occurred there, the employment is principally located there, the employee's activities were supervised there, the state has a significant connection with the issue of workmen's compensation, or the parties have agreed that their rights should be determined in accordance with the workmen's compensation statute of that state. Since it is the purpose of such statutes to preclude the question of tortious liability, the right to an award is determined by the wording of the various compensation statutes. It is provided in $\S 184$, however, that the question of immunity from tortious liability shall be governed by the law of the state which awarded compensation, and if, by the law of a state in which the employer was required to provide insurance, the employer, once an award has been made, is declared immune from further liability, that immunity will be upheld.

In the writer's opinion, the American use of the "proper law" concept has been beneficial. It has not produced the grave uncertainty which some writers forecast. By contrast, it has led to a more consistent and rational approach by the segregation of issues and the development of more specific guidelines for different torts. It has been successfully applied to employment injuries involving compensation schemes, and multistate torts alike. What uncertainty there is, and there has necessarily been some in the early development of the concept, has been dissipated as a body of case law has built up. It is submitted that a similar "proper law" approach would prove beneficial in Canada. If this concept is to be "borrowed", it should be a selective, rather than a wholesale "borrowing". The present writer's preference, for the reasons stated, would exclude the policy-analysis gloss which has formed a superstructure on the "proper law"

290 See Magnolia Petroleum Co. v. Hunt (1943) 320 U.S. 430 (U.S. Supreme Court) per Stone C.J. If a "proper law" approach is used, it would not be necessary to determine whether the conduct is justifiable or not justifiable by the lex loci delicti. Thus, one of the major difficulties is removed. Once the applicable law is indicated, that law will determine whether or not there is a right of action. 
approach. None of the five factors advocated by Leflar ${ }^{291}$ except the desire for predictability, warrants acceptance by Canadian courts. What should be accepted is an objective determination, qualitative and quantitative, to determine which law has the most significant relationship to the precise issue in dispute. If this concept were developed the conflicts rules for torts would not lead to uncertainty, nor would they fail to achieve justice. It is submitted that the approach has merits, far outweighing the inadequate and obsolete Phillips v. Eyre doctrine.

\section{A PROPER LAW APPROACH}

That this approach should have been adopted is significant. Until this development advocates of the "proper law" ${ }^{202}$ could look only to contract as a relevant analogy, but now the field of divorce recognition is also a relevant analogy. The basic rules of contract and foreign divorce recognition, enunciated in a century of little travel or international intercourse, have been found wanting. The rule in Phillips v. Eyre ${ }^{203}$ is in the same position - it is submitted that the same approach can be adopted in torts as in the other areas. Nor would there be any uncertainty, it is submitted, in most of the cases other than those which give rise to difficulty under the existing rules. Gow does not share this optimism and expresses his criticism as follows: ${ }^{204}$

It has been suggested elsewhere that there is nothing to prevent English courts from applying English law to a tort committed in Scotland by one Englishman against another, the ground for this suggestion being that the court should look to the proper law of the tort. With respect it is submitted that such reasoning would land in absurdity.
How is the proper law of the tort to be determined? Why in the case figured should English law be applied? - because the parties are English? What then will be the proper law of a tort committed in Eire by a Frenchman against a Portuguese and the action is raised in the court of a country other than Eire?

However, in stating this criticism, Gow has inadvertently stated some of the reasons why a proper law should be applied. One might reply to his hypothetical example by asking - what is the particular tort involved? What specific issue is at stake between the parties? Would it be fair as between the parties to limit the enquiry to the lex fori and the lex loci delicti? Do these two legal systems have anything more than a mere fortuitous connection with the case in question? All these are relevant questions, not met by the traditionalists, yet each is capable of being considered and dealt with under a "proper law" approach.

Furthermore, a "proper law" approach would relieve the court of the onerous duty of determining what is the locus delicti (which task was shown earlier ${ }^{295}$ to be not an easy exercisel). The mechanical tests which might be applied were shown earlier to be rather inadequate. A "proper law" approach would obviate the necessity of fixing a locus delicti and the appropriate weight, in the circumstances, could be given to factors such as the place where the negligent act occurred, or the place where damage was suffered.

The criticism that uncertainty would be introduced into the law has been met in other areas, particularly contracts and matrimonial causes, where a "proper law" approach has operated. It has not been suggested in these fields that too great a degree of uncertainty has resulted, yet exactly the same decision making process has to be used. Some would say that it is not possible to argue by analogy from contract to tort, that there is an element of foresight in contract which is not present in tort. In contract, the parties may regulate for events in

201 Supra, n. 269.

202 See e.g., Morris, supra, n. 76 at 883.

293 Supra, n. 4.

294 Supra, n. 197 at 316.

205 See IV at 32 et seq. 
advance and will often need to know by what law a contract is governed before it is made. ${ }^{206}$ It is this difference, however, which relieves tort law from a criticism that has been levelled at contract law. It is not necessary to know in advance by what law a tort will be governed. Such a question is generally posterior rather than anterior to the commission of a tort. As Morris puts it: ${ }^{207}$

A motorist does not legitimately need to know what law will determine his liability to pay damages if he runs down a pedestrian. His social duty is not to run the pedestrian down; he ought not to be concerned (at least until after the accident) with the question whether the law imposes upon him a strict liability or only a duty of care, or whether his liability is to be governed by the law of State $X$ or the law of State $Y$. A duty not to cause harm is a good rule socially, though it may not always hold good in the domestic law of torts.

It is suggested therefore, that a sufficient degree of certainty is still present in a "proper law" approach, in that duties not to injure or to defame, for example, are sufficiently well-defined in order to allow a person to regulate his affairs without regard to the law which may govern his action in the event of his committing a wrong.

\section{Present judicial attitudes to the proper law doctrine}

The "proper law" doctrine is not without support in the various courts of the Commonwealth, and among text-book writers on this subject. ${ }^{208}$ The doctrine has perhaps taken its most developed form in the United States where it has been applied in several leading cases. ${ }^{299}$ The case of Babcock v. Jackson, ${ }^{300}$ is regarded by many as the leading American authority on the subject. In that case three New York residents embarked on a weekend trip to Canada in a car licensed and insured in New York. While driving in Ontario the driver lost control of the car and collided with an adjacent stone wall. Upon his return to New York the plaintiff brought an action against the driver. The conflict arose in that there was in force in Ontario (the locus delicti) a guest statute barring actions by gratuitous passengers, but in New York (the forum) there was no similar rule. The problem presented by the case was that the law provided by the usual New York conflicts rule (the place of wrong rule) was quite fortuitous, and in order to meet this problem the court resorted to the "proper law" doctrine, deciding that New York law had the most significant connection with the case and that that law should therefore be applied. In his comments on the "proper law" doctrine Fuld J. made the following statements: ${ }^{301}$

Justice, fairness and "the best practical result" may best be achieved by giving controlling effect to the law of the jurisdiction which, because of its relationship or contact with the occurrence or the parties, has the greatest concern with the specific issue raised in the litigation. The merit of such a rule is that it gives to the place having the most interest in the problem paramount control over the legal issues arising out of a particular factual context and thereby allows the forum to apply the policy of the jurisdiction most intimately concerned with the outcome of the particular litigation ....

This approach has not resulted in a distinct forum-bias and the same court, in a later case, thought the emphasis disclosed by the facts sufficiently different to warrant the application of a law other than the lex fori. ${ }^{302}$

200 Especially, e.g., with respect to moneys for payment and account, if these are different. See e.g., R. v. International Trustee for Bondholders A.-G. [1937] A.C. 500. 297 Supra, n. 76 at 895.

${ }^{209}$ See Graveson, supra, n. 111 at 617; Castel, Conflict of Laws 897 (2d ed 1968); Anton, supra, n. 28 at 244; Mygh, Conflict of Laws in Australia 351-352 (1968).

209 See e.g., Kilberg v. North East Airlines, supra, n. 79; Griffiths v. United Airlines (1964) 203 A. (2d) 796 (Supreme Court of Pennsylvania); Dym v. Gordon, supra, n. 258.

800 Supra, n. 49.

301 Id. at 287.

302 Dym v. Gordon, supra, n. 258. 
This approach has been adopted quite widely in the United States and Babcock v. Jackson has been followed in later cases, such as Kilberg v. North East Airlines, ${ }^{303}$ Griffiths v. United Airlines, ${ }^{304}$ Dym v. Gordon, ${ }^{305}$ Miller v. Miller. ${ }^{306}$ The acceptance of the doctrine is such that it has been taken as the basis for the Restatement (Second) in Conflict of Laws. ${ }^{307}$

The general principle is set out there as follows: ${ }^{308}$

(1) The rights and liabilities of the parties with respect to an issue in tort are determined by the local law of the state which, as to that issue, has the most significant relationship to the occurrence and the parties under the principles stated in $\$ 6$.

(2) Contacts to be taken into account in applying the principles of $\$ 6$ to determine the law applicable to an issue include:

(a) the place where the injury occurred,

(b) the place where the conduct causing the injury occurred,

(c) the domicile, residence, nationality, place of incorporation and place of business of the parties, and

(d) the place where the relationship, if any, between the parties is centered.

These contacts are to be evaluated according to their relative importance with respect to the particular issues.

This general statement is followed by particular rules relating to the specific torts, each of which adopts the same principle but gives additional guidance for the particular tort in question. Thus in defamation, the local law of the state where the publication took place will in most cases be applied.908

In Canada, the traditional rules have also come under criticism from writers and judges. In the case of Abbott-Smith v. Governors of the University of Toronto ${ }^{310}$ the court was required to consider the traditional rules for determination of the locus delicti. In the course of his judgment Currie J. commented on the views of Harper ${ }^{311}$ and went on to say: ${ }^{312}$

If one day there is to be effective clarification of Order XI (1), or if the opportunity

is taken to apply a new doctrine, then I should prefer that the doctrine be that of the proper law of the tort as propounded by Professor J. H. C. Morris in "Proper Law of a Tort' (1951), 64 Harvard Law Rev. 886.

This suggestion has been taken up, albeit guardedly, by the British Columbia Supreme Court, in the case of Gronlund et. al. v. Hansen. ${ }^{318}$ Smith, Co. Ct. J., based his decision on both the traditional grounds and the "proper law" doctrine. However, in the course of his opinion, he suggested that the "proper law" could profitably be adopted. Smith J. adopted the dictum of Lord Denning in Boys v. Chaplin $^{314}$ in which he (Lord Denning) applied the "proper law" of the tort. It would appear, therefore, that there is judicial support for the adoption of the "proper law", 310 which attitude is strengthened by the views of the Commissioners

${ }^{803}$ Supra, n. 79.

304 Supra, n. 299.

sos Supra, n. 258.

808 (1968) 36 U.S.L. Week 2674.

sor Restatement, supra, n. 5.

308 Id. at s. 145 .

300 Id. at s. 150 .

310 Supra, n. 117.

811 Harper, Tort Cases in the Conflict of Laws, (1955) 33 Can. Bar Rev. 1155.

312 Supra, n. 117 at 690.

813 Supra, n. 80.

814 Supra, n. 3.

$815 \mathrm{Id}$. at 20.

316 See e.g., Harding, Common Law, Federal and Constitutional Aspects of Choice of Law in Tort, (1965) 7 U. West. Aust. L. Rev. 196 at 229: "The sooner a way can be found to extricate Australian 'conflicts' problems from the rule in Phillips v. Eyre the better it will be for a legal system that wants to cope flexibly with social needs." See also Lavan v. Danyluk (1970) 75 W.W.R. 500 (B.C.S.C.). 
of Uniformity of Legislation. In their tentative draft for a model tort rule they suggested the "proper law" doctrine: ${ }^{317}$

(1) When deciding the rights and liabilities of the parties to an action in tort the court shall apply the local law of the state which has the most substantial connection with the occurrence and with the parties regardless of whether or not the wrong is of such a character that it would have been actionable if committed in this Province.

(2) When determining whether a particular state has a substantial connection with the occurrence and the parties, the court shall consider the following important contacts:

(a) the place where the injury occurred;

(b) the place where the conduct occurred;

(c) the domicile and place of business of the parties; and

(d) the place where the relationship, if any, between the parties is centered.

(3) When deciding which state, among the states having any contact with section 2 , has the most substantial connection with the occurrence and the parties, the court shall consider chiefly the purpose and policy of each of the rules of local law that is proposed to be applied.

In Australia too, there has been some criticism of the traditional rules. In $K o o p$ v. Bebb $b^{328}$ the infant plaintiffs, brought an action in negligence against the drivers of a truck in which their father had been killed. The accident occurred in New South Wales and the father died in hospital in Victoria. The High Court $^{319}$ expressed dissatisfaction with the rules, especially as developed in Machado v. Fontes. The court stated that "the last word has not been said on the subject",, 20 and as a result this case has been widely cited for its expression of dissatisfaction with the traditional rules.

The "proper law" doctrine in England was brought to a head in the case of Boys v. Chaplin, ${ }^{821}$ in which the plaintiff was suing the defendant for negligent driving while both parties were temporarily resident in Malta, serving in the British Armed Forces. Under Maltese law the plaintiff would have recovered only actual expenses ( 253 ) but in England he could also recover damages for pain and suffering and future loss (£2303). In the Court of Appeal ${ }^{322}$ English law was applied and the higher damages awarded. Lord Justice Diplock dissented, adhering rigidly to the traditional rules. Lord Upjohn allowed the greater sum on the basis that some flexibility was required in the traditional rules. Lord Denning was in favour of applying the "proper law" doctrine to the quantification of damages and to the heads of damages. He stated his opinion quite clearly: "I am of the opinion that in these cases we should apply the law of the country with which the parties and the act done have the most significant connexion. This has been called the "proper law of the tort" ".323 In the Court of Appeal, the majority was not in favour of the "proper law" approach, but was dissatisfied with the rules as they stood. A similar situation prevailed in the House of Lords. Lord Hodson was fully in favour of the "proper law" approach:"324

I would for myself, therefore, adopt the American Law Institute Restatement (second) Conflict of Laws (Proposed Official draft lst May 1968) set in the speech ... [of] ... Lord Wilberforce. If controlling effect is given to the law of the jurisdiction which because of its relationship with the occurrence has the greater concern with the specific issue raised in the litigation, the ends of justice, are likely to be achieved, as the American authorities show, there is a difficult task presented for the dissenting judgments in the Appellate Courts.

3171966 Proceedings at 58.

318 Supra, n. 104.

310 Id. at 643.

$820 \mathrm{Id}$.

821 Supra, n. 152.

322 Supra, n. 3.

828 Id. at 20.

824 Supra, n. 152 at 380. 
I would accordingly, in agreement with the Master of the Rolls, treat the law of England as applicable since even though the occurrence took place in Malta this was overshadowed by the identity and circumstances of the parties, British temporarily serving in Malta.

Neither Lord Guest nor Lord Donovan was in favour of the "proper law". The latter was content to accept the traditional rules, accepting however, that Machado v. Fontes ${ }^{325}$ was an abuse rather than an application of the traditional rules. Lord Wilberforce presented a lengthy and considered opinion in which he argued for some flexibility in the rules but could not see his way to doing this by way of a "proper law" approach. Instead, he argued, the flexibility could be achieved by segregating the issues involved in the case. ${ }^{326}$ There appears to be a paradox here, in that Lord Wilberforce declined to accept the "proper law" doctrine, but by segregating the issues, he is incorporating a fundamental element of that doctrine, but did state the "proper law" as a possibility. The alternative, in his view, was to require actionability by both the lex fori and the lex loci delicti, but this suffered from the defect that on facts such as those in the present case, an exception would have to be admitted in order for the plaintiff to recover. It would appear, therefore, that Lord Pearson was taking very cautious steps towards a "proper law" doctrine.

In England, it appears, the House of Lords has leaned towards the "proper law" doctrine, but has passed by a sound opportunity to put torts in the conflict of laws on a more rational basis. Perhaps the motive for this hesitancy is caution, but now the introduction of such a new rule is dependent upon a factual situation such as Boys v. Chaplin ${ }^{327}$ arising again.

The text-book writers have been more explicit in their advocacy of the "proper law" doctrine. Morris has been advocating the doctrine for many years, ${ }^{328}$ and his suggestions are referred to by Cheshire, ${ }^{329}$ who argues that a "crude" recourse to a "proper law" doctrine might compound the confusion. Graveson ${ }^{330}$ includes a section entitled "The Need for a New Basis of Liability in Tort", in which he favours the adoption of the "proper law" doctrine based on the American Restatement. Anton argues in favour of a "proper law" approach with the emphasis being given to the lex loci delicti:as1

The present writer believes that in most cases the lex loci delicti is the appropriate law to govern delicts with international aspects, but he is prepared to concede that the connecting factor should be the "proper law" of the delict, if a presumption in favour of the lex loci delicti were admitted.

It is submitted that too cautious an approach has been adopted towards torts in conflict of laws and that the time has come to substitute a new rule for the much criticised and inadequate traditional rules.

It is the author's submission that the substituted rule should be that recommended by the Conference of Commissioners on Uniformity of Legislation in Canada. ${ }^{332}$ It is submitted that the new rule would provide a substantial basis for the development of the law in this area and in particular: (i) The necessity of applying the lex fori, and more particularly the substantive law of the forum, would be obviated by the substitution of the "local law of the state which has

325 Supra, n. 88.

326 Supra, n. 152 at 391.

327 Id.

${ }^{328}$ In fact, since 1951. See, supra, n. 76 at 883.

329 Cheshire, supra, n. 35 at 254.

330 Graveson, supra, n. 111 at 617.

331 Anton, supra, n. 28 at 247.

882 Supra, n. 317. 
the most substantial connection with the occurrence and with the parties." ${ }^{328}$ (ii) Under the substituted rule the applicable law would, to a large extent, be uniform regardless of the choice of forum. (iii) It would no longer be necessary to fix specifically the lex loci delicti, since this would be adequately canvassed in the points of contact dealt with in section 2 of the suggested rules. (iv) Differences of policy between a foreign law and the lex fori would be more appropriately dealt with under the concept of "public policy". (v) The blurring of the distinction between choice of law and jurisdiction, inherent in the old rules, would be removed by the suggested rule. (vi) The suggested rule would be in accord with the trend of conflict of laws and particularly the development in contracts and recognition of foreign divorce. ${ }^{334}$ (vii) The suggested rule would be adequate to do justice in cases arising from the increased intercourse between different jurisdictional units. (viii) The suggested rule would deal more adequately with cases made more complex by the presence of contributory negligence or vicarious liability. ${ }^{335}$

\section{APPENDIX I}

A large proportion of litigation before the courts at the present time is somehow related to the operation of motor vehicles, and some would suggest that this proportion is inordinately large. To counteract this imbalance some jurisdictions have moved towards no-fault insurance so that litigation, hopefully, would be reduced. Other jurisdictions have not reached this stage but at least enforce compulsory insurance. It is submitted that a "proper law" approach to motor vehicle accidents in a conflicts context would also be fitting, since many different issues would arise out of a motor vehicle accident, according to the parties to an action. Such parties might be driver and passenger, driver and driver, driver and pedestrian. In each case, the issue raised might be significantly different, and the "proper" or "applicable" law might be different although the different actions arise out of the same accident.

It would not be contrary to a "proper law" approach to make more specific the term "real and substantial connection", and this, it is submitted, is what is attempted in a draft Conflict of Laws (Traffic Accidents) Act submitted to the Uniformity Commissioners in August, 1970. The model act is based on the Convention on the Law Applicable to Traffic Accidents adopted by the Eleventh Session of the Hague Conference on Private International Law. The stated purpose of the framer of the act, Mr. Hugo Fischer, is to provide firm rules for determining the law to be applied to tortious liability arising from traffic accidents, and thereby bring certainty, uniformity, and justice, and prevent "forum-shopping".

The crux of the model act is the choice of law rules contained in sections 3 to 7. The ground rule is that the applicable law is the place where the accident occurred, though this may be displaced by the law of the place of registration or the law where the vehicle was habitually stationed, in appropriate circumstances. For example, in an action between a driver and a pedestrian, where the car was registered and the pedestrian was habitually resident in the same place, the law of the place of registration would be the applicable law.

It is submitted that such a model act is in no way inconsistent with a "proper law" approach. In most cases, the place having the most real and substantial connection with the action will be the place where the accident occurred. On the other hand, that law would probably not be the "proper law"

sas Id. Model Tort Rule.

s84 Supra, V.

ass See e.g., Brown v. Poland and Emerson Motors Ltd. (1952) 6 W.W.R. (N.S.) 368 (Alberta Supreme Court); O'Conner v. Wray [1930] S.C.R. 231. 
in an action between driver and passenger, where the car was registered in the same place as the passenger had his habitual residence.

It is submitted that the model act is a set of specific rules following a "proper law" approach. This is buttressed by the fact that the rules relate only to choice of law and not jurisdiction, and the "applicable law" so chosen governs all substantive, but not procedural, questions arising out of the particular action. Moreover a general clause allowing the bypassing of the applicable law indicated by the rules is included, thus introducing the concept of "public policy" clearly into the consideration.

The model act is at present merely a discussion draft before the Uniformity Commissioners, and has not, of course, been passed into law in any province of Canada. Indeed, the whole question of acceding to Conventions produced by the Hague Conference demands prior consideration. It would, however, be a significant change in our conflicts rules, if passed, and, it is submitted, go a long way to introducing a "proper law" approach into a large number of cases appearing before the courts.

\section{APPENDIX II}

Restatement of the Law Second, Conflict of Laws.

Tentative Draft No. 8 (1963) at 2

Section 379. The General Principle

(1) The local law of the State which has the most significant relationship with the occurrence and with the parties determines their rights and liabilities in tort.

(2) Important contacts that the forum will consider in determining the state of most significant relationship include:

(a) the place where the injury occurred,

(b) the place where the conduct occurred,

(c) the domicile, nationality, place of incorporation and place of business of the parties, and

(d) the place where the relationship, if any, between the parties is centered.

(3) In determining the relative importance of the contacts, the forum will consider the issues, the character of the tort, and the relevant purposes of the tort rules involved.

\section{Commissioners on Uniformity of Legislation in Canada Foreign Torts Act}

(1) When deciding the rights and liabilities of the parties to an action in tort the court shall apply the local law of the state which has the most substantial connection with the occurrence and with the parties regardless of whether or not the wrong is of such a character that it would have been actionable if committed in this Province.

(2) When determining whether a particular state has a substantial connection with the occurrence and the parties the court shall consider the following important contacts:

(a) the place where the injury occurred,

(b) the place where the conduct occurred,

(c) the domicile and place of business of the parties, and

(d) the place where the relationship, if any, between the parties is centered.

(3) When deciding which state, among the states having any contacts within section 2, has the most substantial connection with the occurrence and the parties, the court shall consider chiefly the purpose and policy of each of the rules of local law that is proposed to be applied. 